\title{
Assessment of critical minerals: updated application of an early-warning screening methodology
}

\author{
Erin McCullough ${ }^{1} \cdot$ Nedal T. Nassar ${ }^{1}$
}

Received: 9 May 2017 / Accepted: 10 September 2017 / Published online: 19 September 2017

(C) The Author(s) 2017. This article is an open access publication

\begin{abstract}
Increasing reliance on non-renewable mineral resources reinforces the need for identifying potential supply constraints before they occur. The US National Science and Technology Council recently released a report that outlines a methodology for screening potentially critical minerals based on three indicators: supply risk $(R)$, production growth $(G)$, and market dynamics $(M)$. This early-warning screening was initially applied to 78 minerals across the years 1996 to 2013 and identified a subset of minerals as "potentially critical" based on the geometric average of these indicators - designated as criticality potential $(C)$. In this study, the screening methodology has been updated to include data for 2014, as well as to incorporate revisions and modifications to the data, where applicable. Overall, $C$ declined in 2014 for the majority of minerals examined largely due to decreases in production concentration and price volatility. However, the results vary considerably across minerals, with some minerals, such as gallium, recording increases for all three indicators. In addition to assessing magnitudinal changes, this analysis also examines the significance of the change relative to historical variation for each mineral. For example, although mined nickel's $R$ declined modestly in 2014 in comparison to that of other minerals, it was by far the largest annual change recorded for mined nickel across all years examined and is attributable to Indonesia's ban on the export of unprocessed minerals. Based
\end{abstract}

Electronic supplementary material The online version of this article (https://doi.org/10.1007/s13563-017-0119-6) contains supplementary material, which is available to authorized users.

Erin McCullough

emccullough@usgs.gov

1 National Mineral Information Center, U.S. Geological Survey, 12201 Sunset Valley Drive, Reston, VA 20192, USA on the 2014 results, 20 minerals with the highest $C$ values have been identified for further study including the rare earths, gallium, germanium, rhodium, tantalum, and tungsten.

Keywords Criticality potential $\cdot$ Risk analysis $\cdot$ Mineral supply chains · Production concentration · Price volatility

\section{JEL Classification Q01}

\section{Introduction}

Modern technology is in large part possible through the use of increasingly complex materials that utilize some of the rarest elements in Earth's upper continental crust. Lithium, cobalt, nickel, and graphite are key components of certain high energy-density rechargeable batteries found in various consumer electronics and, more recently, in hybrid and electric vehicles (Goonan 2012). Indium-tin oxide thin-film coatings are used in liquid crystal displays (LCD), certain solar photovoltaic panels, and energy-efficient windows (Jorgenson and Michael 2005). Germanium is used in various infrared (IR) devices including night vision goggles, binoculars, surveillance cameras, and IR heat-seeking missiles (Butterman and Jorgenson 2005). Uninterrupted access to these and other specialized minerals is thus crucial for both economic development and national security.

There are, however, several factors that may increase the likelihood, or exacerbate the impact, of a supply disruption for some of these minerals. Highly concentrated production in a few politically or socially unstable countries, rapid increases in demand due to the introduction of new and disruptive technologies, inelastic supply due to the mineral being produced solely as a byproduct, limited post-consumer recycling, 
decreasing mineral ores grades, and the lack of adequate substitutes are all examples of such factors.

Non-fuel mineral commodities, which, for simplicity, are referred to hereafter as "minerals," that are at greatest risk of a supply disruption and whose supply disruption would be of most consequence may be considered "critical." The identification and characterization of a mineral as critical has been a subject of increasing interest in recent years (e.g., (Morley and Eatherley 2008; Strategic Materials Protection Board 2008; Rosenau-Tornow et al. 2009; Buchert et al. 2009; Bae 2010; Bauer et al. 2010; Thomason et al. 2010; Bauer et al. 2011; Duclos et al. 2010; European Commission 2010, 2014; Pfleger et al. 2011; Zepf et al. 2011; Graedel et al. 2012, 2015; Moss et al. 2013; Roelich et al. 2014; Coulomb et al. 2015; British Geological Survey 2016). In March 2016, the Subcommittee on Critical and Strategic Mineral Supply Chains under the US National Science and Technology Council published a report that outlines a methodology for screening potentially critical minerals based on three fundamental indicators (supply risk, production growth, and market dynamics) in order to provide an early-warning mechanism for identifying potential supply constraints before they occur (US National Science and Technology Council 2016). This early-warning screening, which is briefly described in the next section, was applied to 78 minerals across the years 1996 to 2013 and identified a subset of minerals as "potentially critical." Several in-depth studies have been undertaken to better understand the risks and vulnerabilities associated with this subset of minerals. This work is ongoing.

In this study, the early-warning screening methodology has been updated to include new data for the year 2014 as well as to incorporate revisions and modifications to historical data, where available. The results across all years are contained herein but special attention is directed towards identifying how the overall measure of criticality potential changed from the year 2013 to 2014 for each of the individual indictors.

\section{Methodology and scope}

Based on the methodology outlined by the subcommittee, (US National Science and Technology Council 2016), the categorization of a mineral as critical is conducted in two distinct stages as illustrated in Fig. 1. The first stage provides an earlywarning screening that identifies minerals as "potentially critical" based on three indicators: supply risk $(R)$, production growth $(G)$, and market dynamics $(M)$. These indicators were selected because they capture different aspects of mineral criticality and because of their complementary nature: $R$ is an assessment of production concentration at the country-level weighted by each country's governance rating, $G$ quantifies growth in a mineral's global production to capture changes in its market size, and $M$ tracks the mineral's price volatility (US National Science and Technology Council 2016).

Utilizing annualized world production statistics, annual average prices (or trade values), and country governance ratings, these indicators are calculated for each mineral and across all years before being normalized to obtain values on a common 0 to 1 scale. Greater values indicate a relatively higher degree of concern. The geometric mean of these three indicators is then calculated to provide an overall measure of criticality potential $(C)$. As noted in the initial report by the subcommittee, the geometric mean was selected in order to provide an appropriate measure of central tendency without assuming perfect substitution across the indicators (US National Science and Technology Council 2016). Mathematical formulas describing the calculation of each of the indicators and data sources are provided in Sections 1 and 2 of the Online Resources, respectively.

Minerals identified as "potentially critical" based on this early-warning screening are then subject to further analysis in the second stage. These in-depth analyses involve different kinds of studies (e.g., geological, material flow, or sectoral analyses) that are customized in order to address concerns raised in the early-warning screening for the mineral in question. Several in-depth studies have been completed and several more are in progress. A list of the completed studies is presented in Section 3 of the Online Resource.

In the initial application of the screening methodology, 78 minerals were examined up to the year 2013. This included 50 individual elements of the periodic table, as well as the rare earths (i.e., the lanthanides) as a single mineral category, feldspar, fluorspar, mica, monazite, and eight ferroalloys: ferrochromium, ferromanganese, ferromolybdenum, ferronickel, ferroniobium, ferrosilicon, ferrovanadium, and silicomanganese. In addition, multiple production stages were analyzed separately for magnesium (Mg), aluminum (Al), titanium (Ti), iron $(\mathrm{Fe})$, cobalt $(\mathrm{Co})$, nickel $(\mathrm{Ni})$, copper $(\mathrm{Cu})$, zinc $(\mathrm{Zn})$, tin $(\mathrm{Sn})$, lead $(\mathrm{Pb})$, and bismuth $(\mathrm{Bi})$ to determine the process step that has the highest degree of criticality. All minerals examined in the initial application are reexamined and updated in this assessment as indicated in Fig. 2 with the exception of tellurium. Tellurium is excluded from this assessment due to the lack of comprehensive global production statistics. There is, however, an ongoing effort to develop a sufficient production dataset, at which point tellurium will be revaluated in the early-warning screening.

In addition to including new data for the year 2014, data for previous years have been updated based on revisions made by the referenced data sources. Beyond these revisions, an effort was made to review and improve the uniformity of mineral price data utilized in this assessment. In some instances, the time-series price data utilized in the previous assessment included differing forms of the same commodity that were not necessarily comparable in value. This thus caused artificial 
Fig. 1 Overview of methodology (US National Science and Technology Council 2016)
Stage I:

Early Warning Screening
Stage II:

In-Depth Analysis

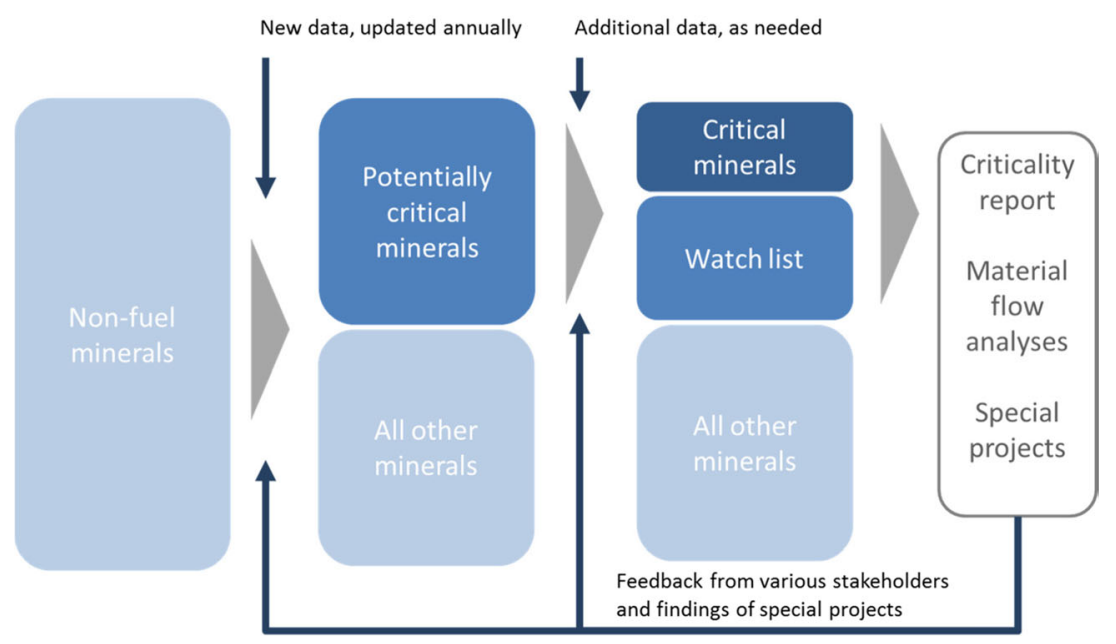

movements in the $M$ indicator. For example, in the previous assessment, the price data utilized for beryllium was based on the yearend beryllium metal market price up to the year 2000 . The reporting of this price information was, however, discontinued and thus for the years 2001 to 2013, the price

of beryllium-copper master alloy-a major berylliumcontaining commodity (Lederer et al. 2016) —was utilized instead. This caused an artificial increase in $M$ for this mineral starting in year 2001. To avoid this issue, the price of beryllium contained in the beryllium-copper master alloy was

\begin{tabular}{|c|c|c|c|c|c|c|c|c|c|c|c|c|c|c|c|c|c|}
\hline $\begin{array}{c}\mathrm{H} \\
\text { Hydrogen }\end{array}$ & & & & & & & & & & & & & & & & & $\begin{array}{c}\mathrm{He} \\
\text { Grade-A and } \\
\text { crude helium } \\
\text { production }\end{array}$ \\
\hline $\begin{array}{l}\mathrm{Li} \\
\text { Lithium } \\
\text { minerals } \\
\text { and brine } \\
\text { production }\end{array}$ & $\begin{array}{c}\mathrm{Be} \\
\text { Beryl } \\
\text { production }\end{array}$ & & & & & & & & & & & $\begin{array}{c}\text { B } \\
\text { Boron } \\
\text { minerals } \\
\text { production }\end{array}$ & $\begin{array}{c}\text { C } \\
\begin{array}{c}\text { Natural } \\
\text { graphite } \\
\text { production }\end{array}\end{array}$ & $\begin{array}{c}\mathrm{N} \\
\text { Nitrogen }\end{array}$ & $\begin{array}{c}0 \\
\text { oxygen }\end{array}$ & $\begin{array}{c}\mathbf{F} \\
\text { Fluorspar } \\
\text { production }\end{array}$ & $\begin{array}{l}\mathrm{Ne} \\
\text { Neon }\end{array}$ \\
\hline $\begin{array}{l}\mathrm{Na} \\
\text { sodium }\end{array}$ & \begin{tabular}{|c|}
$\mathrm{Mg}$ \\
Magnesium \\
metal primary \\
production \\
\end{tabular} & & & & & & & & & & & $\begin{array}{c}\text { Al } \\
\text { Aluminum } \\
\text { smelter } \\
\text { sroduction } \\
\end{array}$ & $\begin{array}{c}\mathrm{Si} \\
\begin{array}{c}\text { Silicon metal } \\
\text { production }\end{array}\end{array}$ & \begin{tabular}{|c|}
$\mathrm{P}$ \\
$\begin{array}{c}\text { Phosphate } \\
\text { rock } \\
\text { production }\end{array}$ \\
\end{tabular} & $\begin{array}{c}\mathrm{S} \\
\text { Sulfur } \\
\text { production }\end{array}$ & $\begin{array}{c}\mathrm{Cl} \\
\text { chlorine }\end{array}$ & $\begin{array}{l}\mathrm{Ar} \\
\text { Argon }\end{array}$ \\
\hline $\begin{array}{c}\mathrm{K} \\
\begin{array}{c}\text { Marketable } \\
\text { potash } \\
\text { production }\end{array} \\
\end{array}$ & $\begin{array}{l}\mathrm{Ca} \\
\text { Calcium }\end{array}$ & $\begin{array}{c}\text { SC } \\
\text { Scandium }\end{array}$ & \begin{tabular}{|c|}
$\mathrm{Ti}$ \\
Titanium \\
sponge \\
production
\end{tabular} & $\frac{\mathrm{V}}{\substack{\text { Vanadium } \\
\text { production }}}$ & \begin{tabular}{c|}
$\mathrm{Cr}$ \\
$\begin{array}{c}\text { Chromite } \\
\text { production }\end{array}$ \\
\end{tabular} & \begin{tabular}{|c|} 
Mn \\
Manganese \\
ore \\
production \\
\end{tabular} & \begin{tabular}{c|}
$\mathrm{Fe}$ \\
Iron ore \\
production
\end{tabular} & $\begin{array}{c}\text { Co } \\
\text { Cobalt } \\
\text { refinery } \\
\text { production }\end{array}$ & \begin{tabular}{|c|}
$\mathrm{Ni}$ \\
Nickel \\
plant \\
production
\end{tabular} & $\begin{array}{c}\mathrm{Cu} \\
\text { Copper } \\
\text { refinery } \\
\text { production }\end{array}$ & \begin{tabular}{|c|}
$\mathrm{Zn}$ \\
Zinc \\
smelter \\
production
\end{tabular} & $\begin{array}{c}\mathrm{Ga} \\
\text { Gallium } \\
\text { production }\end{array}$ & $\begin{array}{c}\mathrm{Ge} \\
\text { Germanium } \\
\text { refinery } \\
\text { production }\end{array}$ & \begin{tabular}{|c|} 
As \\
$\begin{array}{c}\text { Arsenic } \\
\text { trioxide } \\
\text { production }\end{array}$ \\
\end{tabular} & $\begin{array}{c}\text { Se } \\
\text { Selenium } \\
\text { refinery } \\
\text { production }\end{array}$ & $\begin{array}{c}\mathrm{Br} \\
\begin{array}{c}\text { Bromine } \\
\text { production }\end{array}\end{array}$ & $\begin{array}{l}\mathrm{Kr} \\
\text { Krypton }\end{array}$ \\
\hline $\begin{array}{c}\mathrm{Rb} \\
\text { Rubidium }\end{array}$ & \begin{tabular}{c|}
$\mathrm{Sr}$ \\
$\begin{array}{c}\text { Celestite } \\
\text { production }\end{array}$
\end{tabular} & $\begin{array}{c}\mathrm{Y} \\
\begin{array}{c}\text { ntrium oxide } \\
\text { mine } \\
\text { production }\end{array} \\
\end{array}$ & \begin{tabular}{|c|}
$\mathrm{Zr}$ \\
Zrconium \\
mineral \\
concentrate \\
production
\end{tabular} & $\begin{array}{c}\mathrm{Nb} \\
\text { Niobium } \\
\text { mineral } \\
\text { concentrate } \\
\text { production }\end{array}$ & \begin{tabular}{|c|} 
Mo \\
Molybdenum \\
mine \\
production
\end{tabular} & \begin{tabular}{|c|} 
TC \\
Techretium
\end{tabular} & \begin{tabular}{|c|} 
Ru \\
Ruthenium \\
production
\end{tabular} & $\begin{array}{c}\text { Rh } \\
\begin{array}{c}\text { Rhodium } \\
\text { production }\end{array}\end{array}$ & $\begin{array}{c}\mathrm{Pd} \\
\begin{array}{c}\text { Palladium } \\
\text { production }\end{array}\end{array}$ & $\begin{array}{c}\text { Ag } \\
\text { Silvermine } \\
\text { production }\end{array}$ & \begin{tabular}{|c|}
$\mathrm{Cd}$ \\
Cadmium \\
refinery \\
production
\end{tabular} & \begin{tabular}{|c|} 
In \\
$\begin{array}{c}\text { Indium } \\
\text { refinery } \\
\text { production }\end{array}$ \\
\end{tabular} & \begin{tabular}{|c|}
$\mathrm{Sn}$ \\
$\begin{array}{c}\text { Tin } \\
\text { smelter } \\
\text { production }\end{array}$
\end{tabular} & $\begin{array}{c}\mathrm{Sb} \\
\begin{array}{c}\text { Antimony } \\
\text { mine } \\
\text { production }\end{array} \\
\end{array}$ & \begin{tabular}{|c|} 
Te \\
Tellurium \\
refinery \\
production
\end{tabular} & \begin{tabular}{|c|}
1 \\
$\begin{array}{c}\text { Crude iodine } \\
\text { production }\end{array}$
\end{tabular} & $\begin{array}{l}\mathrm{Xe} \\
\text { Xenon }\end{array}$ \\
\hline $\begin{array}{l}\text { Cs } \\
\text { Cesium }\end{array}$ & $\begin{array}{c}\mathrm{Ba} \\
\begin{array}{c}\text { Barite } \\
\text { production }\end{array}\end{array}$ & $\begin{array}{c}\text { La-Lu } \\
\text { Rare earth } \\
\text { oxide mine } \\
\text { production }\end{array}$ & $\begin{array}{l}\mathrm{Hf} \\
\text { Hafnium }\end{array}$ & $\begin{array}{c}\text { Ta } \\
\text { Tantalum } \\
\text { mineral } \\
\text { concentrate } \\
\text { production }\end{array}$ & $\begin{array}{c}\text { W } \\
\begin{array}{c}\text { Tungsten } \\
\text { concentrate } \\
\text { production }\end{array}\end{array}$ & $\begin{array}{c}\mathrm{Re} \\
\begin{array}{c}\text { Rhenium } \\
\text { production }\end{array}\end{array}$ & $\begin{array}{l}\text { Os } \\
\text { Osmium }\end{array}$ & $\begin{array}{c}\text { Ir } \\
\text { Iridium } \\
\text { production }\end{array}$ & $\begin{array}{c}\mathrm{Pt} \\
\begin{array}{c}\text { Platinum } \\
\text { production }\end{array}\end{array}$ & $\begin{array}{c}\text { Au } \\
\text { Gold mine } \\
\text { production }\end{array}$ & $\begin{array}{c}\mathrm{Hg} \\
\begin{array}{c}\text { Mercurymine } \\
\text { production }\end{array} \\
\end{array}$ & $\begin{array}{c}\mathrm{Tl} \\
\text { Tha lium }\end{array}$ & $\begin{array}{c}\mathrm{Pb} \\
\text { Lead } \\
\text { refinery } \\
\text { production }\end{array}$ & \begin{tabular}{|c|}
$\mathrm{Bi}$ \\
Bismuth \\
refinery \\
production
\end{tabular} & $\begin{array}{l}\text { Po } \\
\text { Polonium }\end{array}$ & $\begin{array}{c}\text { At } \\
\text { Astatine }\end{array}$ & $\begin{array}{l}\mathrm{Rn} \\
\text { Radon }\end{array}$ \\
\hline $\begin{array}{c}\mathrm{Fr} \\
\text { Frandium }\end{array}$ & $\begin{array}{l}\mathrm{Ra} \\
\text { Radium }\end{array}$ & $\begin{array}{l}\text { Ac-Lr } \\
\text { Actinides }\end{array}$ & $\begin{array}{c}\text { Rf } \\
\text { Rutherfordium }\end{array}$ & $\begin{array}{l}\mathrm{Db} \\
\text { Dubnium }\end{array}$ & $\begin{array}{c}\mathrm{Sg} \\
\text { Sesborgium }\end{array}$ & $\begin{array}{l}\text { Bh } \\
\text { Bohrium }\end{array}$ & $\begin{array}{l}\text { Hs } \\
\text { Hassium }\end{array}$ & $\begin{array}{c}\mathrm{Mt} \\
\text { Metnerium }\end{array}$ & $\begin{array}{c}\text { DS } \\
\text { Darmstadtium }\end{array}$ & $\begin{array}{c}\mathrm{Rg} \\
\text { Roentgenium }\end{array}$ & $\begin{array}{c}\mathrm{Cn} \\
\text { Copernicium }\end{array}$ & $\begin{array}{l}\mathrm{Nh} \\
\text { Nihonium }\end{array}$ & $\begin{array}{c}\mathrm{FI} \\
\text { Flerovium }\end{array}$ & $\begin{array}{c}\text { Mc } \\
\text { Moscovium }\end{array}$ & $\begin{array}{c}\text { LV } \\
\text { Livermorium }\end{array}$ & $\begin{array}{c}\text { Ts } \\
\text { Tennessine }\end{array}$ & Og \\
\hline
\end{tabular}
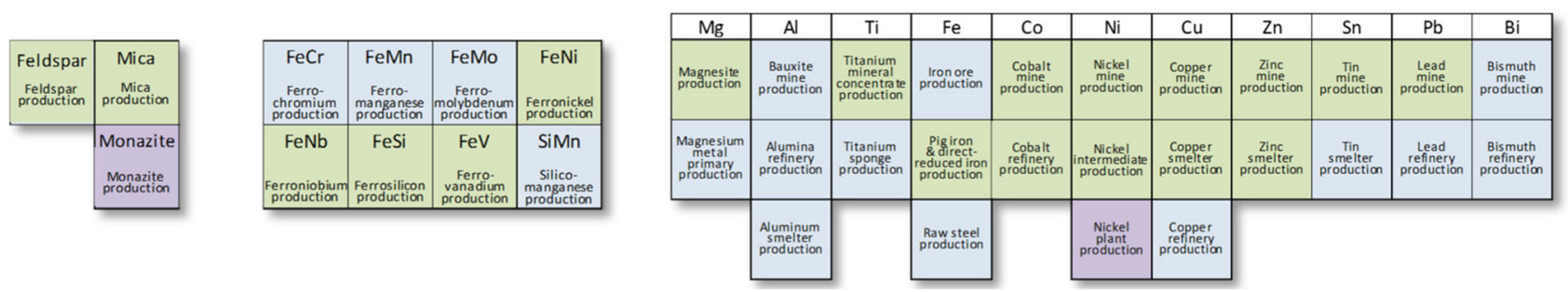

Fig. 2 Scope of minerals (by production stage) included in this assessment as indicated by the color shading. Minerals with green and purple shading indicate those for which alternative or modified price and production data have been utilized, respectively. Minerals shaded with orange had modifications to both price and production data. This a reflection of modifications beyond regular revisions made by the referenced data sources. Tellurium, shaded in red, was included in the previous assessment but is excluded from this assessment 
utilized in this assessment for the entire time-series. Similar adjustments for uniformity were made for several other minerals including helium, rhenium, and silicon. In other cases, more representative price data were utilized. For example, in the previous assessment, manganese price data were based on the annual average value of the combined US imports of manganese ores and ferromanganese. In this update, the reported price of manganese ores (cost, insurance, and freight, at US ports) is utilized instead. Similar adjustments were made for several other minerals including titanium, magnesite, and mica.

Another enhancement to this update has been in the inclusion of different price data for the minerals with multiple processing stages. In the previous assessment, the same price data were utilized for multiple production stages of the same mineral. For example, the same price data were used for copper mining, smelting, and refining. In order to more accurately capture the situation for the intermediate copper products, three different prices were utilized. Specifically, the unit value of US exports of copper ores and concentrates was used for copper mining, the TC/RC (treatment charge, refining charge; which is a reflection of the copper smelters' profit margins) was used for copper smelting, and the annual average US producer price of copper was retained for copper refining. Similar efforts to include price data for the intermediate products were made, where possible, for the other minerals for which multiple production stages.

Alternative or modified production data were also utilized for a few minerals. Production data for boron, for example, were originally reported in gross weight. To more accurately reflect each country's contribution level, the data were converted to boron content. In the case of germanium, production data utilized in the previous assessment were based on information from the World Mining Congress (Reichl et al. 2015). In this update, approximation by the US Geological Survey based on published data and unpublished estimates were utilized instead. In the case of nickel (plant), the production data utilized in the previous assessment included ferronickel production. Given that ferronickel is analyzed as an independent mineral, the ferronickel component of nickel (plant) production was thus removed in this assessment. For other minerals, production data were modified based on new, additional, or revised information that were not previously available.

A summary of the minerals for which alternative or modified data were utilized are highlighted in Fig. 2.

\section{Results and discussion}

\section{Supply risk $(R)$ indicator}

The normalized $R$ indicator values for each of the minerals examined are displayed in Fig. 3 up to the year 2014. Full tabulation of the results is provided in Section 4 of the Online Resource.

As noted in the initial application of the screening methodology (US National Science and Technology Council 2016), many of the minerals examined can generally be categorized as either having consistently high or consistently low $R$ values. Minerals with consistently high $R$ values, such as the rare earths (Y and $\mathrm{La}-\mathrm{Lu})$, niobium $(\mathrm{Nb})$, ruthenium $(\mathrm{Ru})$, rhodium (Rh), tungsten (W), and iridium (Ir), are those in which production is highly concentrated in a few countries where the risk of disruption due to poor governance, as quantified by the World Bank (Kaufmann and Kraay 2016), is a concern. Minerals with consistently low $R$ indicator values, such as bauxite, sulfur (S), iron ore (Fe), copper $(\mathrm{Cu})$, silver $(\mathrm{Ag})$, and gold $(\mathrm{Au})$, have widely dispersed production in a large number of countries, which serves to offset the risk associated with any one particular country. The $R$ values for these minerals are not static but they have remained relatively high or low during the time period examined. In contrast, there are several minerals including magnesium $(\mathrm{Mg})$, gallium (Ga), and bismuth (Bi) for which the $R$ values have increased markedly over the same time period.

As discussed in the introduction, the focus of this study is on changes in the indicators' values between years 2013 and 2014. A direct comparison of $R$ values between these 2 years is displayed in a scatterplot format in Fig. 4a. In this subfigure, the $R$ values for the year 2013 are specified on the horizontal axis while the values for the year 2014 are specified on the vertical axis. A point plotted on the diagonal line indicates no change in the $R$ values between the 2 years for that mineral. The further a point is from this diagonal line, the larger the difference, with points plotted above and below the diagonal line indicating higher and lower $R$ values for the year 2014, respectively. As illustrated in Fig. 4a, the minerals with the largest increases in $R$ values between years 2013 and 2014 are magnesium, gallium, titanium (sponge), and tantalum, whereas the minerals with the largest decreases in $R$ values are bismuth (mine), yttrium, rare earths, rhodium, tungsten, and platinum.

Changes in the $R$ value for a specific mineral from 1 year to the next can be attributed to changes in the composite governance index values of the producing countries (i.e., the producing countries are thought to have improved or worsened governance) or changes in the share of global production of the producing countries. As illustrated in Section 5 of the Online Resource, the composite governance index values for a particular country typically do not change significantly from 1 year to the next. This was indeed the case for the values of the vast majority of countries for the year 2014 as compared to the values for the year 2013. Significant changes to the $R$ indicator values can thus be attributed to changes in the producing countries' relative share of global production. Specifically, decreases in the country production 

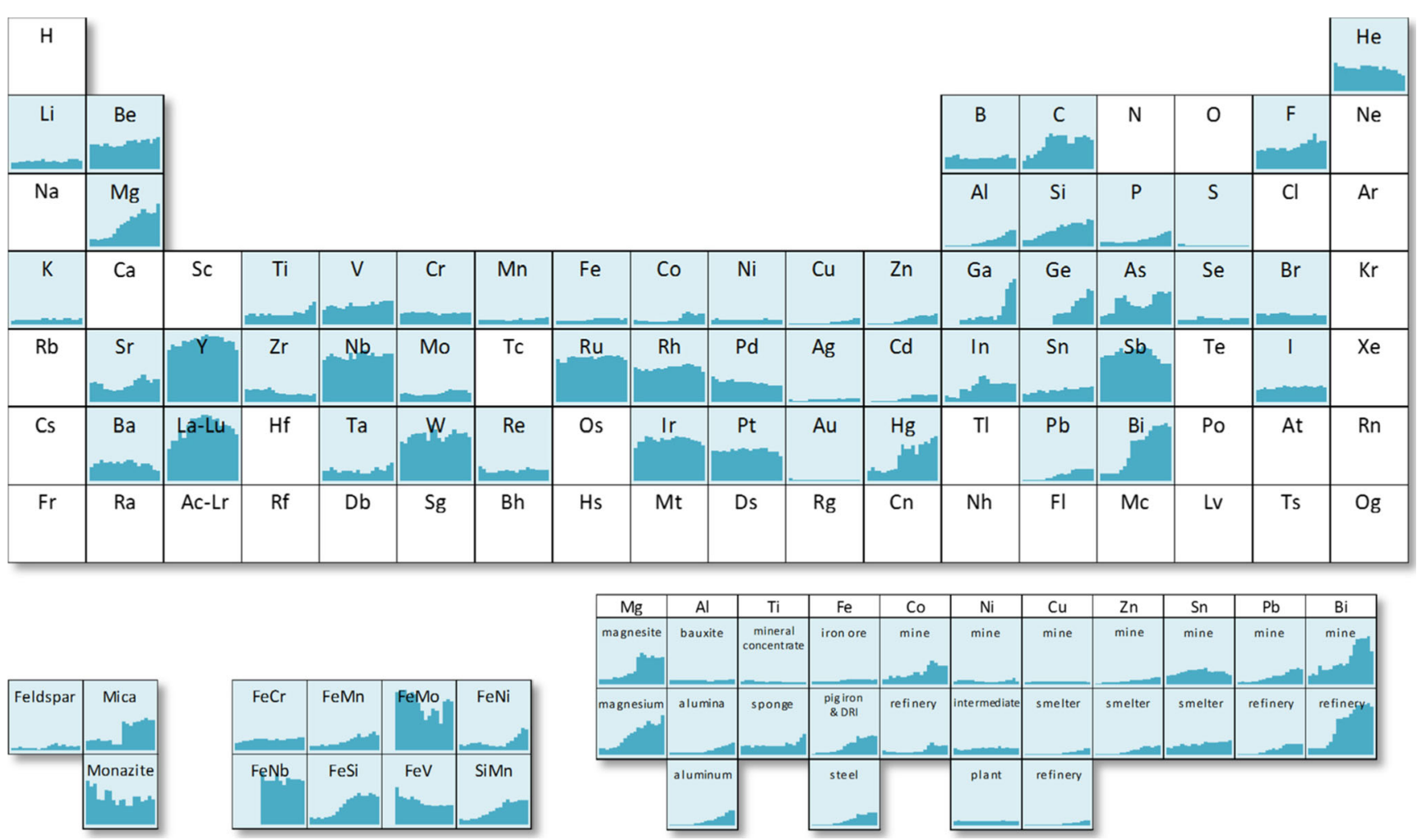

Fig. 3 Supply risk $(R)$ indicator values. For each mineral, the indicator values range from 0 to 1 (vertical axis) over the range of years from 1996 to 2014 (horizontal axis). Values are not available for all minerals for all years

concentration component (i.e., the squaring of each country's production share) of the $R$ values are either due to increases in production by countries that had not previously been major producers or decreases in production by major producers. The decline of the $R$ indicator value of bismuth is due to the former, while the decline in the $R$ indicator value for platinum is due to the latter. In the case of bismuth, Vietnam became a major supplier in 2014-producing nearly $20 \%$ of global product - with the commissioning of the Nui Phao bismuthcopper-fluorspar-tungsten mine (US Geological Survey 2016). The global production of bismuth, which had been dominated by China in 2013, became relatively less concentrated in 2014 as reflected in the decline of its $R$ value from a high of 0.79 in 2013 to 0.53 in 2014 . However, $R$ for bismuth refining remains very high $(0.78)$ due to the concentration of bismuth refining production in China.

In the case of platinum, the largest producer, South Africa, produced significantly less platinum in $2014(93,991 \mathrm{~kg}$ or $64 \%$ of estimated world production) as compared to 2013 $(137,024 \mathrm{~kg}$ or $72 \%$ of estimated world production) (Yager 2016). As a result, the relative concentration of global platinum primary production also declined and platinum's $R$ value decreased from 0.22 in 2013 to 0.19 in 2014 . Note that the decline in South African platinum production was due to a prolonged labor strike (Loferski 2016). It may seem counterintuitive for the $R$ value to decrease after mine labor strikes. However, it is important to remember that the $R$ indicator aims to capture the risk of a supply restriction from the standpoint of the year in question looking forward. As illustrated in Fig. 3 , the $R$ values for the platinum group metals ( $\mathrm{Pt}, \mathrm{Pd}, \mathrm{Rh}, \mathrm{Ru}$, and Ir), all of which are co-produced in South Africa, have been among the highest of all minerals examined. The high $R$ values in previous years were an indication that a relatively large supply disruption from an event such as a labor strike was probable. A lower $2014 R$ value suggests that, all other things being equal, the probability and impact of a supply disruption has been reduced given that production is less concentrated in South Africa. With the labor strike significantly affecting global production, one would expect that the price would have increased notably. The negative impact of the labor strikes would thus have been captured with a higher $M$ value. The negative impact on the market was, however, mitigated due to a decline in overall platinum demand and release of pre-existing inventories (Johnson Matthey 2015). This case emphasizes the importance of in-depth studies in understanding the mineral supply and demand situation beyond what can be ascertained from any set of indicators.

Minerals that had notable increases in their $R$ values include magnesium, gallium, and titanium (sponge). In general, increases in the $R$ values are due to increases in production in the largest producing country. In many cases, including all of the minerals mentioned above, the largest producer is China. It is important to note that, for the $R$ indicator, minerals with relatively high $R$ values are more prone to larger annual 

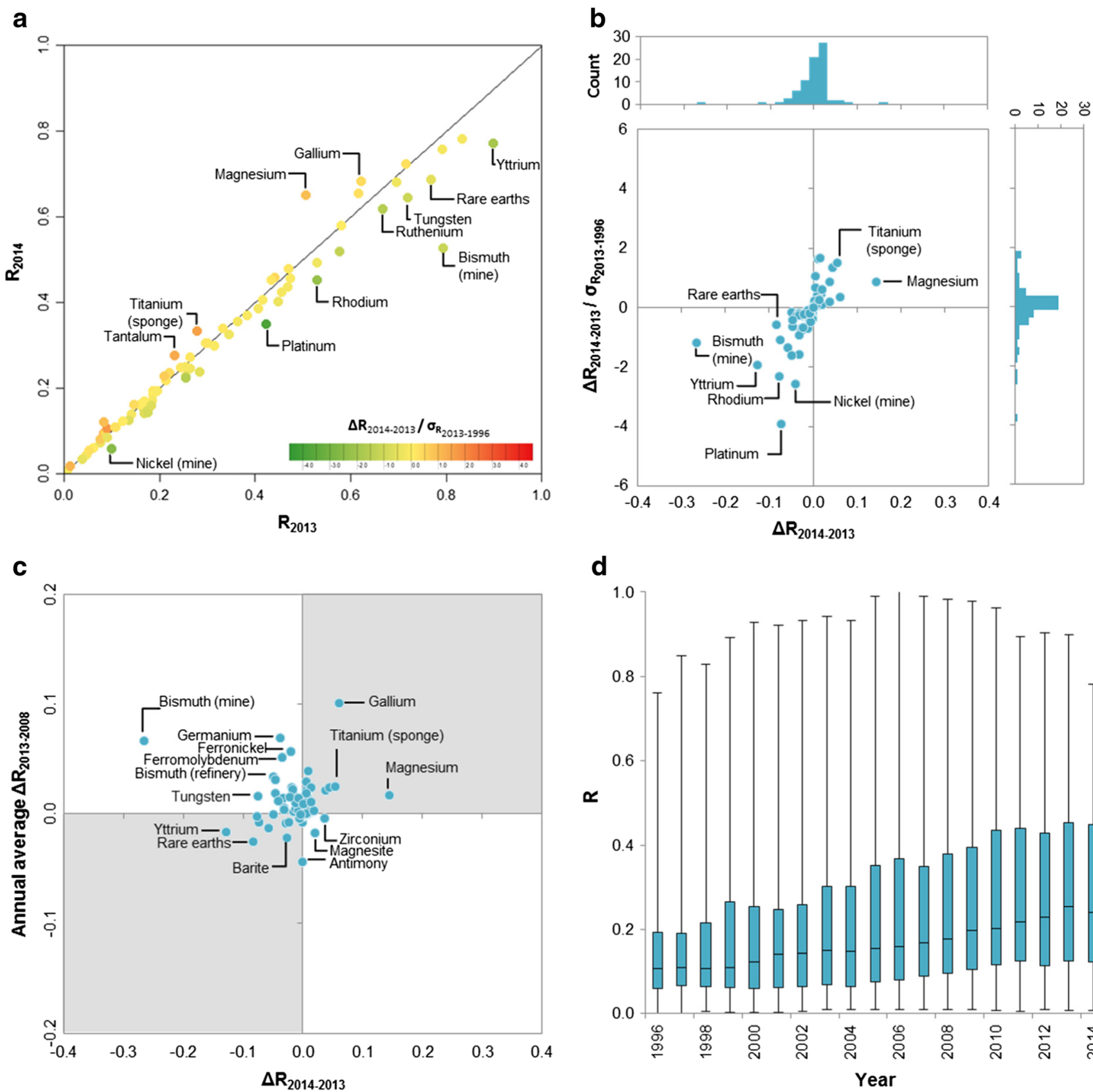

Fig. 4 a Scatterplot of $R$ values for years 2013 (horizontal axis) and 2014 (vertical axis). Distance from diagonal line indicates the magnitude of difference between the 2 years and point shading indicates the significance of that change relative to the standard deviation of $R$ values over previous years. b Scatterplot of the change in the $R$ values between years 2013 and 2014 (horizontal axis) versus the significance of that change (vertical axis). Top and side figures display histograms of their respective axis. c Scatterplot of the change in the $R$ values between years

changes, while those with relatively low $R$ values are less susceptible. This is because relatively high $R$ values are based on the production values of only a few countries and thus even moderate changes in the production of those countries or the emergence of additional producers can result in major changes in the $R$ value. In contrast, relatively low $R$ values are obtained

d

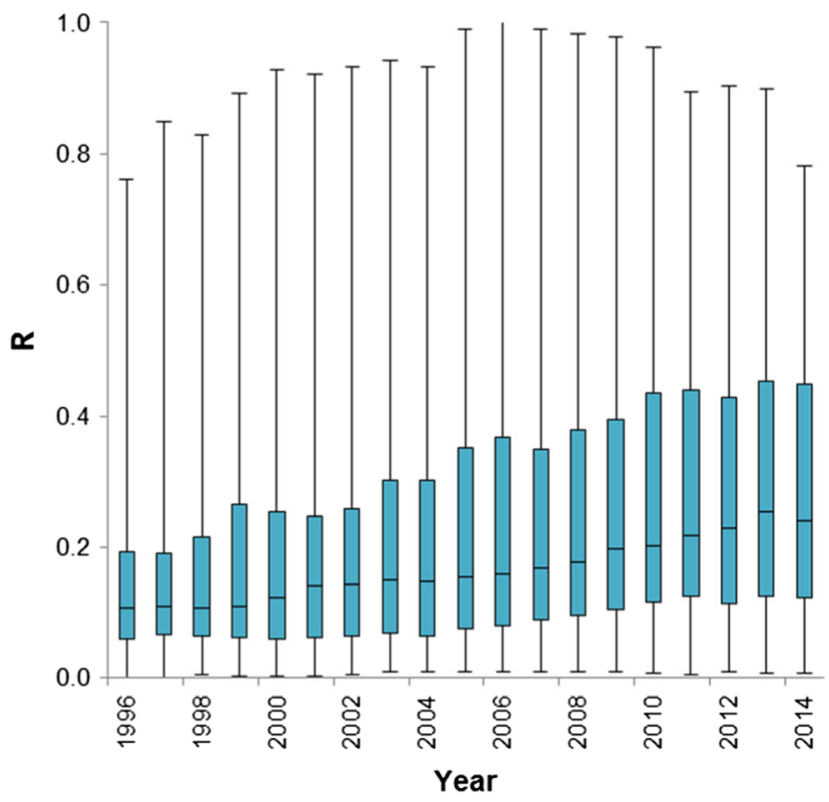

2013 and 2014 (horizontal axis) versus the annual average change in the $R$ values for years 2008 to 2013. Points in the gray quadrants indicate that the change in $R$ values between years 2013-2014 follows the previous 5-year trend, while those in the white quadrants have the opposite trend. $\mathbf{d}$ Distribution of the $R$ values across all minerals via a box-andwhisker plot displaying annual minimums, maximums, and interquartile ranges

where there are a large number of producing countries. Therefore, even major changes will be muted by the large number of producing countries. This was the case for mined nickel. Indonesia, which was the largest mine producer of nickel in 2013, imposed a ban on the export of unprocessed minerals. As a result, Indonesia's production and exports of 
nickel and other minerals declined notably in 2014 (Fig. 5). Despite this major change to the largest producer, the $R$ value for nickel (mine) declined only modestly from 0.10 in 2013 to 0.06 in 2014.

In addition to examining the magnitude of the changes in the indicator values from 1 year to the next, it is also important to determine if these changes are significantly different from what may be considered typical annual variation for that mineral. This is useful for identifying relatively small changes in indicator values that may be atypical for the mineral in question and deemphasize relatively large changes in indicator values for minerals that typically record even larger changes. The change in the $R$ value for nickel (mine), for example, was relatively modest (a decline of 0.04 ). However, this was by far the largest annual change in the $R$ value for nickel (mine) across all years examined. In contrast, the $R$ value for gallium increased by 0.06 points-the second largest recorded increase between these 2 years among all minerals examined-yet this change was smaller than the annual changes recorded for this mineral over the previous 4 years.

To determine how significant the annual change is for a mineral, the value of the annual change is divided by the standard deviation of the indicator values across all years examined up to the year 2013 for each mineral independently. The resultant values can be thought of as the annual change in terms of number of standard deviations. These values are specified via differently colored points in Fig. 4a. The deepest shades of red and green indicate increases and decreases that are greater or less than \pm 4 standard deviations in the $R$ indicator, respectively, and those in yellow indicate changes that are within a single standard deviation.

Figure $4 \mathrm{~b}$ provides a more direct comparison of the magnitude of the 2013-2014 change in the $R$ indicator value (horizontal axis) to the significance of that change using the standard deviation of the indicator value across all years up to the year 2013 (vertical axis). Minerals with relatively large changes in $R$ values between years 2013 and 2014 and for which those changes are significant (i.e., atypical of the past few years) are displayed in the upper right (for increases) and lower left (for decrease) corners of the figure.

As illustrated in the top histogram of Fig. $4 \mathrm{~b}$, the $R$ indicator value for the majority ( 52 of 77 ) of minerals recorded a change with an absolute value of no more than 0.02 and only three minerals (bismuth mine, yttrium, and magnesium) recorded a change with an absolute value greater than 0.1 . Similarly, as illustrated in the side histogram of Fig. $4 \mathrm{~b}$, the change in $R$ was less than one standard deviation for 63 of 77 minerals examined and only nine minerals (platinum, nickel mine, rhodium, yttrium, ruthenium, iodine, titanium sponge, bauxite, and manganese) recorded a change with an absolute value greater than 1.5 standard deviations. For each of these minerals, the significant change in $R$ is due to changes in the quantity of production of that mineral in its largest and/or second largest producing countries. a

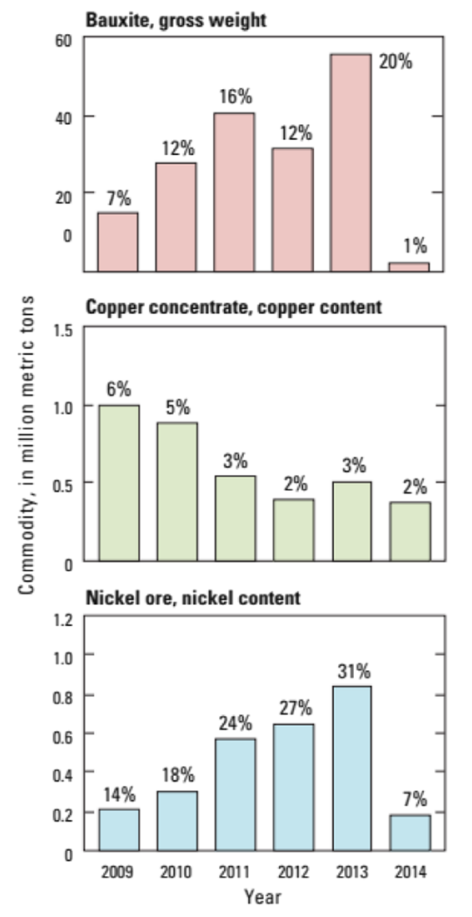

Fig. 5 a Indonesia's annual mine production of bauxite, copper concentrate, and nickel ore from 2009 through 2014 labeled with Indonesia's percent contribution to annual world production. b Value of b

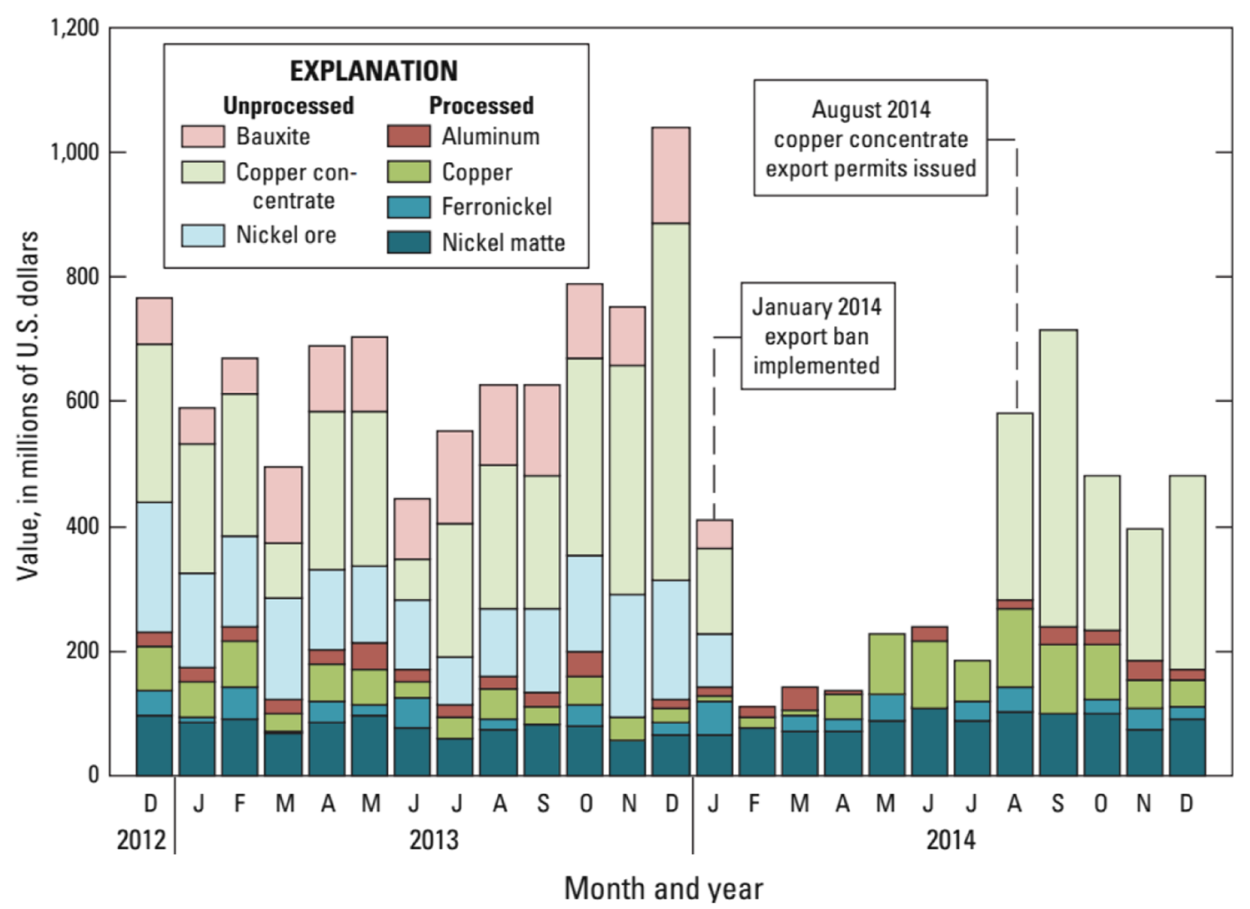

Indonesia's monthly exports of unprocessed mineral ores and processed metals from December 2012 to December 2014. Reproduced from: (Lederer 2016) 
In Fig. 4c, the 2013-2014 change in $R$ value is plotted against the annual average change over the past 5 years to highlight the minerals for which the 2013-2014 change in $R$ value continues or reverse the trend of the past 5 years. The $R$ indicator for bismuth (mine), for example, had been increasing steadily over the past 5 years as China's share of world production grew. With the introduction of bismuth production in Vietnam, the $R$ value reversed the trend and decreased in 2014. This was also the case for 26 other minerals (displayed in the upper left quadrant of Fig. 4c) including tungsten, bismuth (refinery), and ferronickel. There were only seven minerals, including zirconium, magnesite, and niobium, for which the trend reversed in the opposite direction (i.e., from a general decline in $R$ value over the past 5 years to one in which the $R$ value increased in 2014). In these cases, the reason for this reversal is often the resurgence of production in the largest global producers.

It is also useful to compare the overall trends in indicator values across all minerals and years. For the $R$ indicator, the overall trend (Fig. 4d) has been a general increase over time with the median $R$ value increasing steadily from 0.11 in the year 1996 to a high value of 0.25 in 2013. Breaking with this trend, the median value for the year 2014 decreased to 0.24 the first recorded instance of the median $R$ value decreasing. It is not clear if the 2014 results are simply an anomaly for this specific year or a start of a new trend towards lower $R$ values.

\section{Production growth $(G)$ indicator}

The normalized $G$ indicator values for each mineral are displayed in Fig. 6 up to the year 2014. A complete tabulation of the results is also provided in Section 4 of the Online Resource.

As described in the initial application of the early-warning screening (US National Science and Technology Council 2016), the $G$ indicator aims to capture the growth in a mineral's market size by examining recent changes in its global primary production. Minerals, such as gallium, with accelerating growth in production over the time period examined have increasing $G$ values. For most minerals, however, the growth in production is relatively stable. For these minerals, the $G$ indicator values are thus relatively constant over time.

Similar to Fig. 4a, Fig. 7a compares the $G$ values for years 2013 and 2014 in a scatterplot format. Points located along the diagonal line indicate no change in value between the 2 years for those minerals. In general, more minerals had larger changes in their $2014 G$ value than in their $R$ value as indicated by the larger distribution of points away from the diagonal line in Fig. 7a as compared to Fig. 4a. Moreover, the majority of minerals examined (56 of 77) had some degree of increase in their $G$ values as illustrated by the larger number of points above as compared to below the diagonal line in Fig. 7a. The change in the $G$ value in comparison to historical variation of
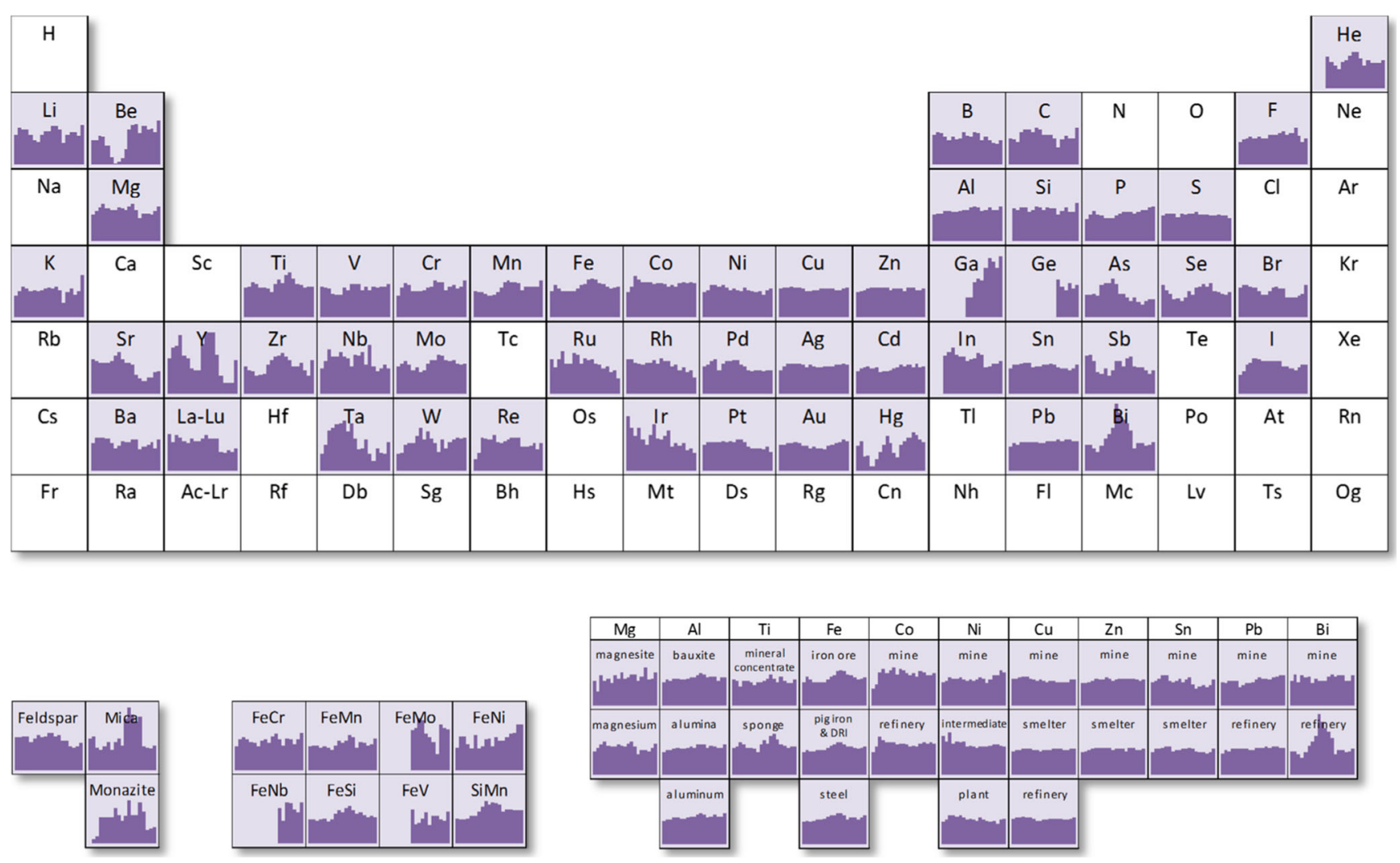

Fig. 6 Production growth $(G)$ indicator values. For each mineral, the indicator values range from 0 to 1 (vertical axis) over the range of years from 1996 to 2014 (horizontal axis). Values are not available for all minerals for all years 
a

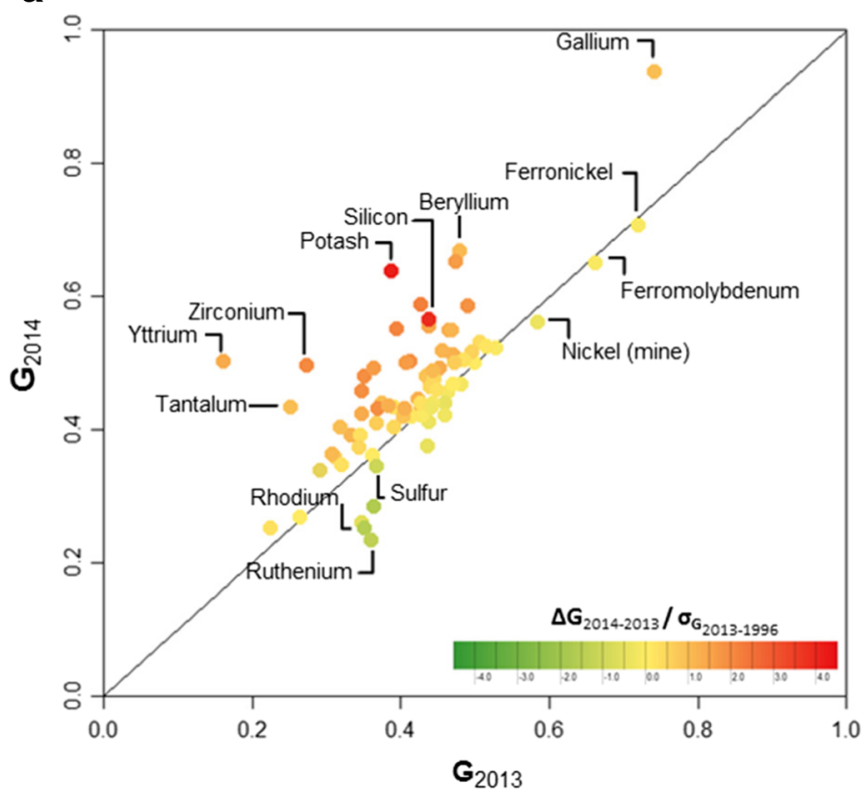

C

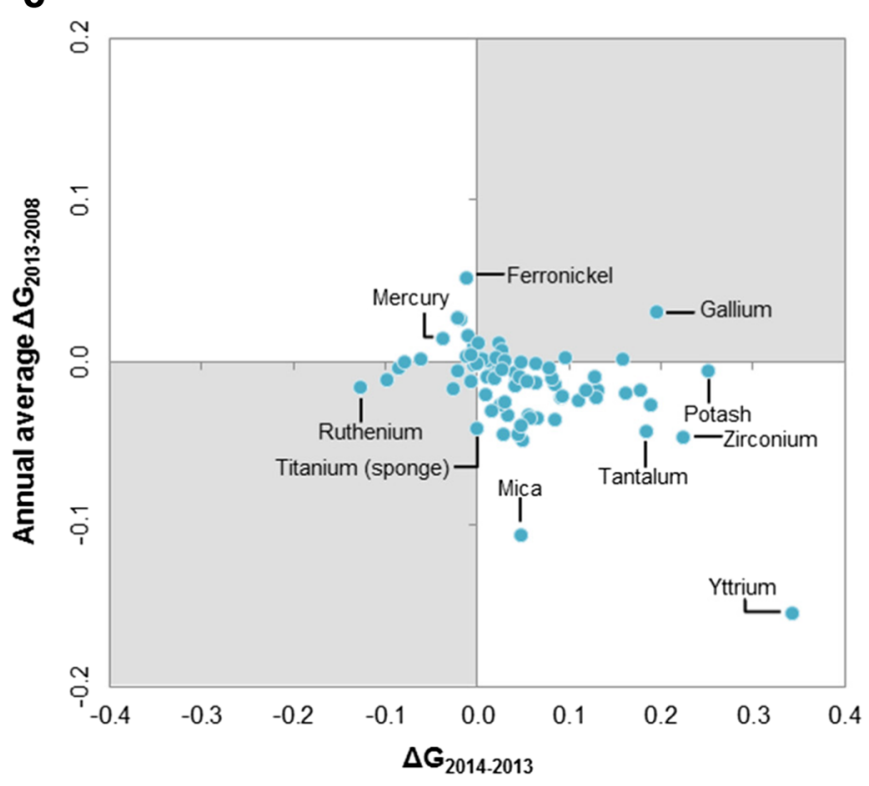

Fig. 7 a Scatterplot of $G$ values for years 2013 (horizontal axis) and 2014 (vertical axis). Distance from diagonal line indicates the magnitude of difference between the 2 years and point shading indicates the significance of that change relative to the standard deviation of $G$ values over the previous years. b Scatterplot of the change in the $G$ values between years 2013 and 2014 (horizontal axis) versus the significance of that change (vertical axis). Top and side figures display histograms of their respective axis. $\mathbf{c}$ Scatterplot of the change in

prior years for each mineral individually, as indicated via the color shading of the points in Fig. 7a, is also of significance to more minerals than is the case for their $R$ values. These three aspects can also be identified in Fig. $7 \mathrm{~b}$ as illustrated by the larger number of minerals in the upper right quadrant in b

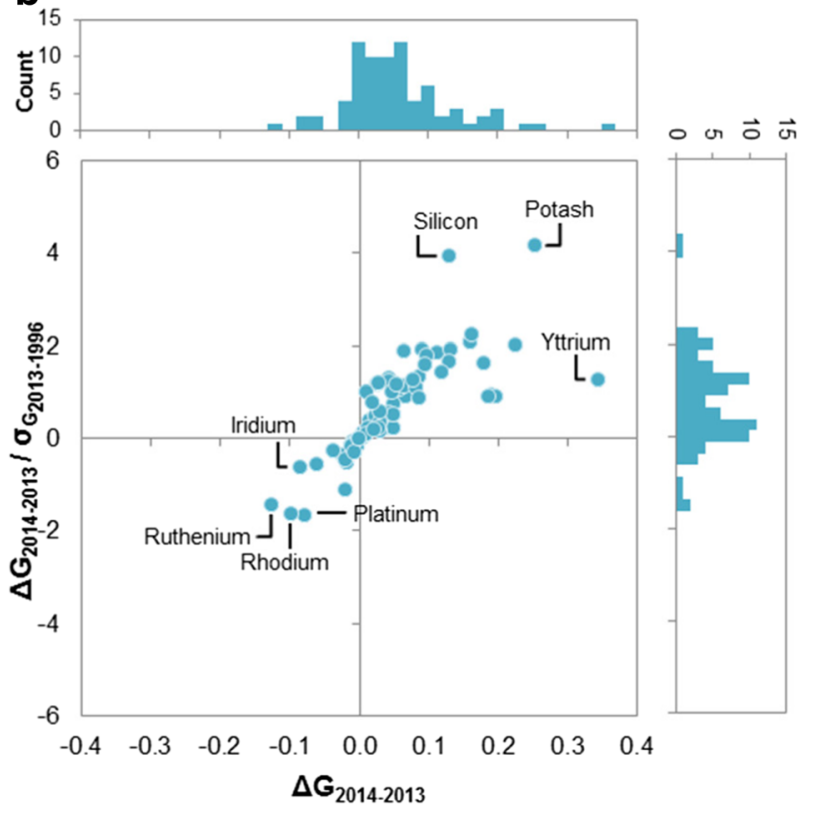

d

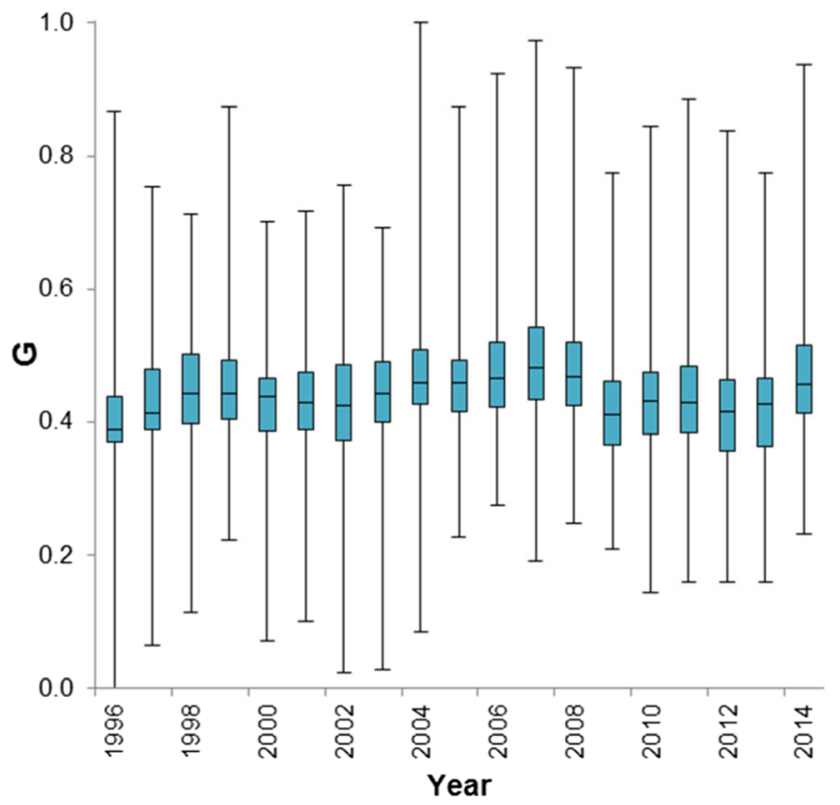

the $G$ values between years 2013 and 2014 (horizontal axis) versus the annual average change in the $G$ values for years 2008 to 2013. Points in the gray quadrants indicate that the change in $G$ values between years 2013-2014 follows the previous 5-year trend, while those in the white quadrants have the opposite trend. d Distribution of the $G$ values across all minerals via a box-and-whisker plot displaying annual minimums, maximums, and interquartile ranges

comparison to the lower left quadrant of the plot and the skewed distributions of the top and left histograms.

The minerals with the largest increases in $G$ values between years 2013 and 2014 are (in descending order) yttrium, potash, zirconium, gallium, and beryllium. In the case of yttrium, 
the increase in $G$ value can be attributed to increased production in China and Australia. For potash, the larger $2014 G$ value has less to do with what occurred between years 2013 and 2014 and more to do with changes between production in years 2008 and 2009. Indeed, although global potash production increased from 35.6 to 40.8 thousand metric tons of $\mathrm{K}_{2} \mathrm{O}$ equivalent from the year 2013 to 2014, it had decreased from 33.7 to 20.8 thousand metric tons from 2008 to 2009 . This combination thus resulted in a significant larger $2014 G$ value for potash as compared to its value for the year 2013. For zirconium, gallium, and beryllium, the higher $G$ value is also due to a combination of lower production in 2009 as compared to 2008 and higher production in 2014 as compared to 2013, especially by their leading producers, Australia, China, and the USA, respectively.

There are only a few minerals, including ruthenium, rhodium, iridium, and platinum, for which the $G$ values declined in 2014. The previously discussed labor strikes in South Africa can account for the decline in $G$ for the platinum group metals (PGMs) given that they are all co-produced with platinum. It is therefore important to recognize how co-produced minerals are dependent upon the health of the market for their primary host commodity. Adverse impact to platinum operations in South Africa similarly affected minerals whose economic viability depends upon co-production.

Figure $7 \mathrm{~b}$ also indicates the significance of production growth for each mineral. Minerals populating the top-right quadrant of the plot experienced the largest magnitudes of production growth (horizontal axis) and change that is aberrant from historical trends (vertical axis).

The increase in $G$ values for 2014 is a reversal of the general trend over the past 5 years for a majority ( 44 of 77 ) of minerals, as illustrated by the number of points in the bottomright quadrant of Fig. 3c. Indeed, for only 22 of the $77 \mathrm{~min}-$ erals have the trends (increases and decreases) continued in 2014. This reversal of trends is even more apparent when examining the distribution of $G$ values across all minerals over several years as illustrated in Fig. 7d. In addition to having a notably tighter distribution of values compared to the $R$ indicator, as indicated by the smaller-sized "boxes" of the boxand-whisker disruptions, Fig. 7d also indicates that $G$ values have a general cyclical pattern. This is likely an indication of historical growth and retraction periods of global minerals industry. The 2014 values suggest a continuation of an upward trend in global mineral production that began in 2012.

\section{Market dynamics $(M)$ indicator}

The normalized $M$ indicator values for each mineral are displayed in Fig. 8 up to the year 2014 with the complete tabulation of the results being provided in Section 4 of the Online Resource.
As illustrated in Fig. 8, in contrast to $R$ and $G$ values, $M$ values show considerable variation over time for the vast majority of minerals. This is often a result of a temporary price spike, as in the case for tantalum in the year 2000, which may not represent a fundamental concern to the mineral's supplydemand dynamics, but rather an indication of the mineral's susceptibility to rapid market fluctuations (US National Science and Technology Council 2016). For several minerals, including bauxite, boron, and graphite, price volatility has been consistently low. In contrast, $M$ values for ruthenium, rhodium, and cadmium have been relatively high over the time period examined.

As noted earlier in the study, one enhancement in this update has been in the inclusion of different price data for the minerals with multiple processing stages where data were available in order to more accurately reflect the situation for the intermediate processes. The impact on the $M$ indicator is most evident within the copper intermediates where copper (smelter) has notably higher $M$ values than either copper (mine) or copper (refinery). This is an accurate reflection of the copper market given the smelters' intermediate position within the supply chain, which makes them susceptible to both supply and demand price volatility based on current market conditions.

Figure 9a illustrates the differences in $M$ values for years 2013 (horizontal axis) and 2014 (vertical axis). In contrast to the $G$ values, $M$ values have decreased in 2014 for the majority (56 of 77) of minerals examined. This can mostly be attributed to the 2008 financial crisis, which significantly affected commodity prices. This is because, similar to $G, M$ encompasses a 5-year retrospective time horizon (i.e., price data for the current year and the previous 5 years).

The $2014 M$ values therefore exclude the volatility associated with 2008 prices that affected $M$ values in previous years. Rhodium, which had the largest decline in $M$ value in 2014, is a prime example of this. In 2008, rhodium's price averaged over $\$ 6500$ per troy ounce, reaching a maximum value of $\$ 10,100$ per troy ounce in June of 2008 before dropping to a low of $\$ 1000$ per troy ounce in December of that year (Johnson Matthey 2016). In comparison to this extreme volatility, the price of rhodium during the 2009-2014 timeframe has remained comparatively stable, ranging from an annual average low of $\$ 1066$ to annual average high of $\$ 2453$ per troy ounce (Johnson Matthey 2016). The exclusion of the price volatility surrounding the year 2008 resulted in a significantly lower $2014 M$ value for rhodium. Other minerals, including cobalt, had similar reasons for their drop in $2014 \mathrm{M}$ values. For yttrium, strontium, and gallium, which had the largest increases in their $201 M$ values among all minerals examined, the increased volatility was due to a decrease rather than an increase in their 2014 prices.

As illustrated Fig. 9b, the $2014 M$ values did not change significantly (i.e., have an increase or decrease with an 

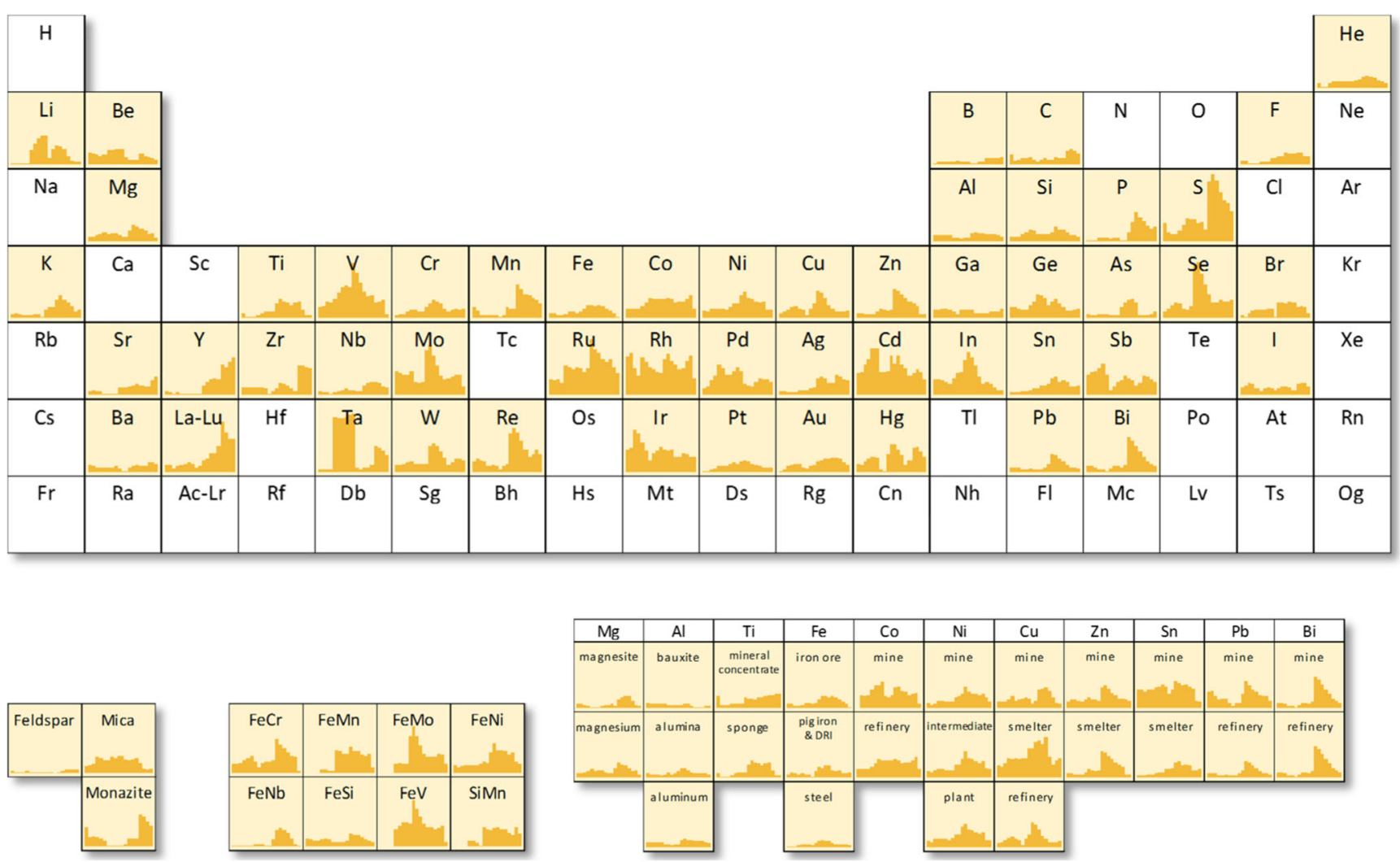

Fig. 8 Market dynamics $(M)$ indicator values. For each mineral, the indicator values range from 0 to 1 (vertical axis) over the range of years from 1996 to 2014 (horizontal axis). Values are not available for all minerals for all years

absolute value greater than one standard deviation) for the vast majority (64 of 77) of minerals. However, there were, as illustrated in Fig. 8c, a number of minerals for which the general trend over the previous 5 -year period was reversed, 15 minerals had $M$ values that, on average, decreased between 2008 and 2013 but increased in 2014, and 14 minerals had $M$ values that, on average, increased between 2008 and 2013 but decreased in 2014 (Fig. 8c). The overall trend in $M$ values across all minerals (Fig. 9d) has been one of general decline since 2008, which can again be attributed to the price volatility of that time period.

\section{Criticality potential $(C)$ indicator}

The $C$ indicator values for each mineral are displayed in Fig. 10 up to the year 2014 with the complete tabulation of the results being provided in Section 4 of the Online Resource.

As described in the "Methodology and scope" section, $C$ is the geometric mean of $R, G$, and $M$, and thus provides an overall assessment of criticality potential based on these three complementary indicators. Minerals, including the minor platinum group metals $(\mathrm{Rh}, \mathrm{Ru}$, and $\mathrm{Ir}$ ) and the rare earths ( $\mathrm{La}-\mathrm{Lu})$ have generally had consistently high $C$ values, while minerals like bauxite, iron ore (Fe), nickel $(\mathrm{Ni})$, copper $(\mathrm{Cu})$, zinc $(\mathrm{Zn})$, silver $(\mathrm{Ag})$, and gold $(\mathrm{Au})$ have had consistently low $\mathrm{C}$ values.
In the initial application of the early-warning screening, a hierarchical cluster analysis was utilized to help determine which subset of minerals should be identified as potentially critical. The analysis used Ward's method (Ward 1963) and the Euclidean distance across all minerals to yield two clusters: one consisting of minerals that would be considered potentially critical and one for all others. The same method was used for the $2014 C$ values. The results indicate a $2014 C$ cutoff value of 0.30 . The 20 minerals with a $2014 C$ value of 0.30 or greater are (in descending order): yttrium and the rare earths (Y, La-Lu), gallium (Ga), ferromolybdenum (FeMo), mercury $(\mathrm{Hg})$, tungsten $(\mathrm{W})$, ruthenium $(\mathrm{Ru})$, antimony $(\mathrm{Sb})$, silicomanganese (SiMn), graphite (listed under carbon, C), germanium $(\mathrm{Ge})$, ferronickel $(\mathrm{FeNi})$, monazite, strontium $(\mathrm{Sr})$, iridium (Ir), tantalum $(\mathrm{Ta})$, rhodium $(\mathrm{Rh})$, bismuth refinery $(\mathrm{Bi})$, niobium $(\mathrm{Nb})$, and phosphate $(\mathrm{P})$.

Aside from mica, magnesite, vanadium $(\mathrm{V})$, bismuth mine (Bi), and cobalt mine (Co), all of the minerals on the 2013 list are also included in this list. It is important to note that for certain minerals, the production and price data for previous years, including 2013 data, have been revised based on new information. For example, global mined tin production in 2013 was revised from 294 to 246 thousand metric tons, with varying degrees of revisions in the production quantities of all producing countries. The $R, G$, and $C$ values for mined tin 
a

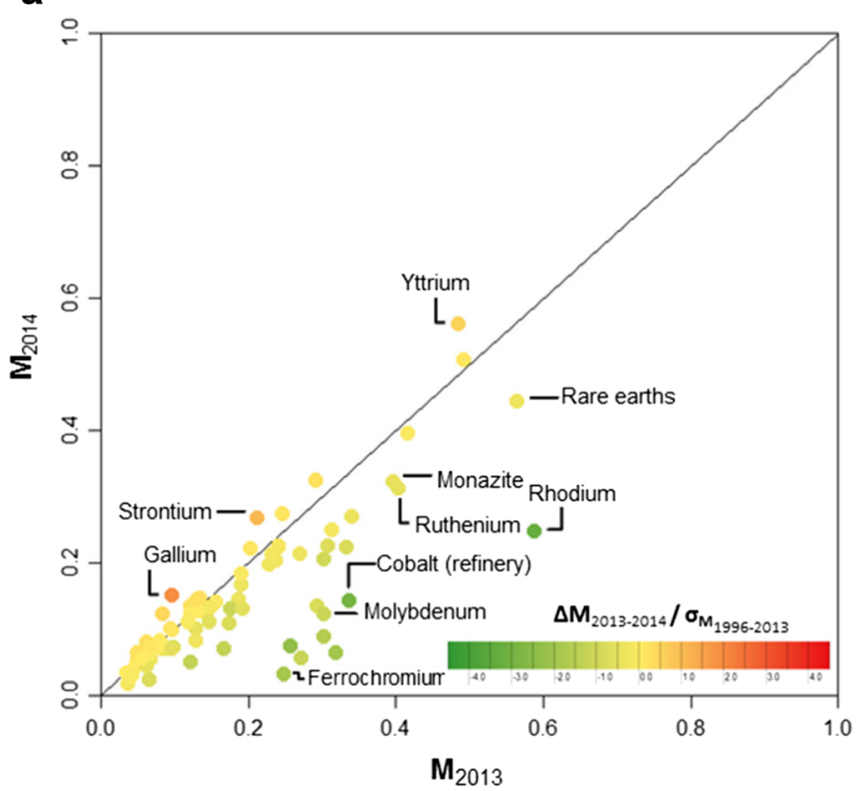

C

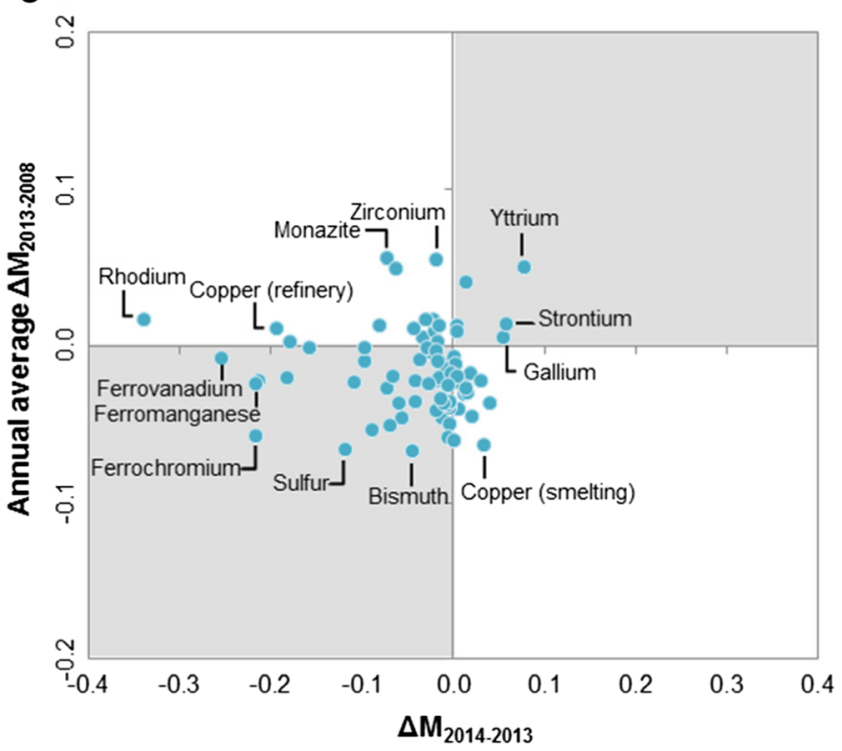

Fig. 9 a Scatterplot of $M$ values for years 2013 (horizontal axis) and 2014 (vertical axis). Distance from diagonal line indicates the magnitude of difference between the 2 years and point shading indicates the significance of that change relative to the standard deviation of $M$ values over the previous years. b Scatterplot of the change in the $M$ values between years 2013 and 2014 (horizontal axis) versus the significance of that change (vertical axis). Top and side figures display histograms of their respective axis. $\mathbf{c}$ Scatterplot of the change in

were thus changed from $0.23,0.41$, and 0.23 to $0.18,0.35$, and 0.19 , respectively. Most minerals had less significant changes, but a few including boron, copper (smelter), lead (mine), magnesite, mica, monazite, niobium, yttrium, and zirconium had notably more significant changes in their $C$ indicator values. These were caused by substantial revisions in the underlying b
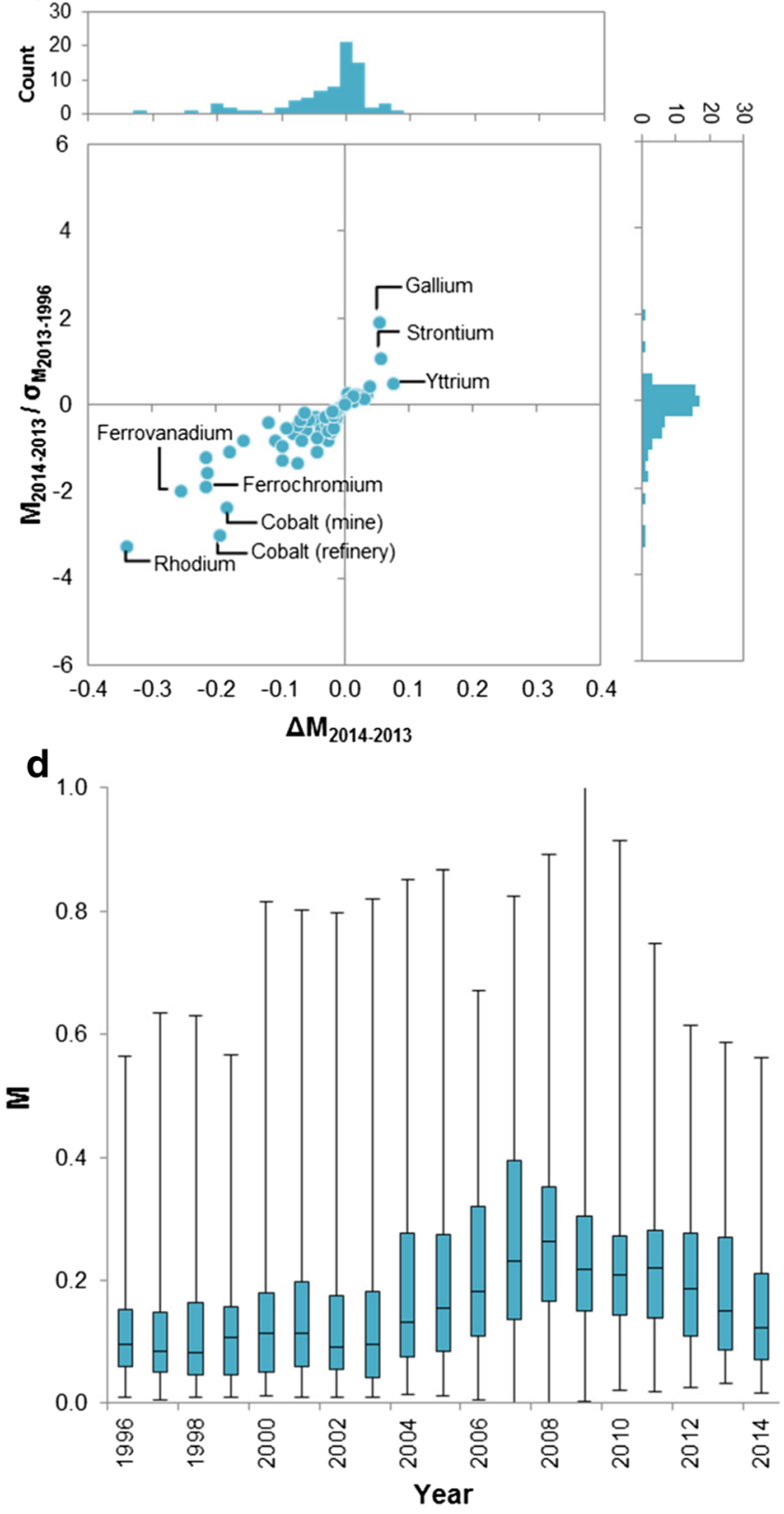

the $M$ values between years 2013 and 2014 (horizontal axis) versus the annual average change in the $M$ values for years 2008 to 2013. Points in the gray quadrants indicate that the change in $M$ values between years 2013 and 2014 follows the previous 5-year trend, while those in the white quadrants have the opposite trend. d Distribution of the $M$ values across all minerals via a box-and-whisker plot displaying annual minimums, maximums, and interquartile ranges

production and/or price data used in the analysis or, as in the case for price data used for copper-smelter, due to the use of an alternative dataset.

Re-calculating the cluster analysis with the updated data for 2013 yields a similar cut-off value of 0.30 with a somewhat different list of minerals above this threshold. A comparison 

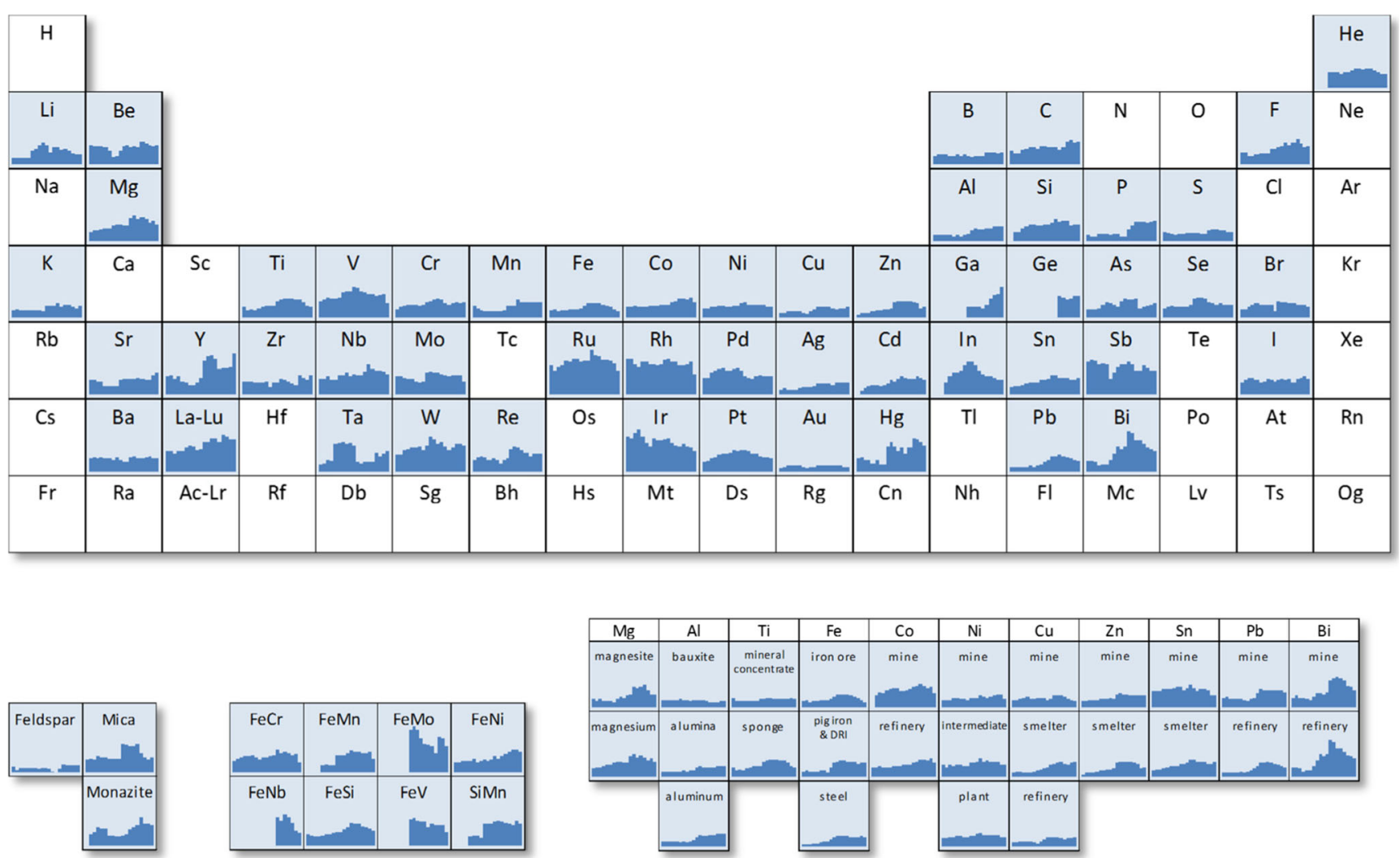

Fig. 10 Criticality potential $(C)$ indicator values. For each mineral, the indicator values range from 0 to 1 (vertical axis) over the range of years from 1996 to 2014 (horizontal axis). Values are not available for all minerals for all years

of the 27 minerals with $C$ values above 0.30 in either year is displayed in Fig. 11.

The specific 2013-2014 changes in $C$ values across all minerals examined are identified in Fig. 12a. Overall, 31 minerals recorded increases in their $C$ values, while 46 recorded decreases. However, for only ten minerals were the absolute values of the changes greater than 0.10 . Specifically, yttrium and gallium, both of which had notably high $C$ values in 2013, increased their $C$ values even further in 2014 by 0.19 and 0.11 , respectively. For gallium, all three indicators increased in 2014. For yttrium, the increase in $C$ is due to an increase in both $G$ and $M$ ( $R$ decreased).

It is important to note that the assessment of $C$ is not a measure of a mineral's availability. Consider the case of yttrium. Yttrium's $C$ indicator increased from 0.41 to 0.60 , the highest recorded value for 2014 among all minerals examined. The increase was due to a combination of increases in $G$ and $M$. As previously discussed, the increase in yttrium's $G$ value in 2014 can be attributed to increased production in China and the ramp-up of the Mt. Weld mining operation in Australia, which also caused yttrium's $R$ to decrease. The increase in price volatility, $M$, was due to a price decline in 2014 . The combination of increased production and declining price suggests that yttrium is becoming more (not less) available, yet the increased $G$ and $M$ values more than offset the decline in $R$ thereby increasing yttrium's $C$ value.
In contrast, rhodium, vanadium, ferrochromium, ferromolybdenum, ferrovanadium, cobalt (mine), ferromanganese, and ruthenium all recorded decreases of more than 0.10 . For rhodium, ruthenium, and ferromolybdenum, the decline in $C$ is due to a decline in all three indicators, while for vanadium, cobalt (mine), ferrochromium, and ferrovanadium, the decline in $C$ is attributable to a decline in $M$ alone. For ferromanganese, both $M$ and $R$ declined. As illustrated in Fig. $12 \mathrm{~b}$, these changes were significant in comparison to historical variation in their respective $C$ values (greater than +1 or less than -1 standard deviation) for all of these minerals. In addition, the 2013-2014 change in $C$ value was significant for zirconium, potash, nickel (mine), molybdenum, cobalt (refinery), and iodine.

The distribution of minerals across all four quadrants of Fig. 12c is an indication that 2014 (and the 2009-2014 versus 2008-2013 time horizons for $G$ and $M$ ) varied non-uniformly for the minerals examined. For ten minerals, including tantalum, gallium, and zirconium, $C$ values continued to increase, while for 33 minerals, including ruthenium, bismuth (mine and refinery), and ferrovanadium, $C$ values continued to decrease. For the remaining 34 minerals, the 5-year trend reversed in 2014, with $C$ values for 13 minerals switching from increasing to decreasing and 21 minerals switching from decreasing to increasing. Across all minerals examined, the median $C$ value declined slightly in 2014, a trend that seems to have begun in 2012 (Fig. 12d). 
Fig. 11 Minerals with criticality potential $(C)$ values greater than the threshold value of 0.30 in either year 2013 (blue) or 2014 (red). Values are presented in descending of $C$ values in the year 2014

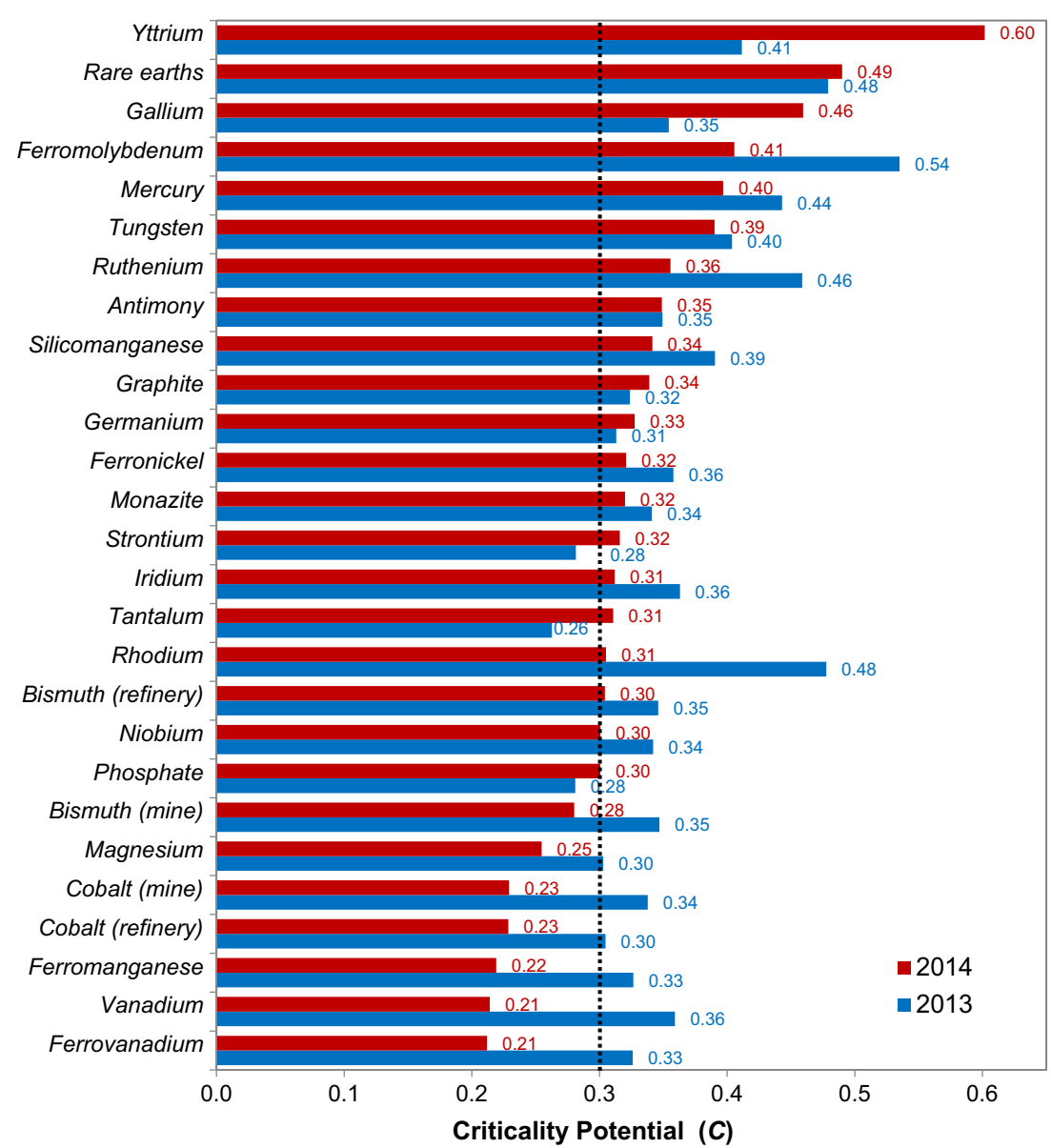

\section{Conclusion}

The early-warning screening methodology has been updated to include data up to the year 2014. The results indicate several notable changes in the 2014 values as compared to the values for the year 2013 across each of the indicators. For the supply risk $(R)$ indicator, more minerals (44) recorded a decline than an increase (33) in $R$ values. The median $R$ value across all minerals examined thus declined for the first time across all years examined (1996-2013). The decline was, however, relatively modest given that the majority (52 of 77) of minerals recorded a change with an absolute value of no more than 0.02 on a common 0 to 1 scale. More minerals also recorded a decline (56) than an increase (11) in their market dynamics $(M)$ indicator value. This was mainly caused by the exclusion of the highly volatile 2008 prices that were included in the calculation of the $2013 M$ values when using a 5-year time horizon. For the production growth $(G)$ indicator, the opposite was the case with 56 minerals recording increasing values. The median $G$ value across all minerals thus also increased and continued an upward trend that seems to be part of a cyclic pattern. With two of the three indicators in decline, the criticality potential $(C)$ indicator thus also declined for the majority (46 out of 77) of minerals.

A hierarchical cluster analysis was conducted and identified a subset of 20 minerals for further study based on a $C$ value greater than 0.30: yttrium $(\mathrm{Y})$, the rare earths $(\mathrm{La}-\mathrm{Lu})$, gallium (Ga), ferromolybdenum (FeMo), mercury (Hg), tungsten $(\mathrm{W})$, ruthenium $(\mathrm{Ru})$, antimony $(\mathrm{Sb})$, silicomanganese $(\mathrm{SiMn})$, graphite (listed under carbon, C), germanium (Ge), ferronickel (FeNi), monazite, strontium ( $\mathrm{Sr}$ ), iridium (Ir), tantalum $(\mathrm{Ta})$, rhodium $(\mathrm{Rh})$, bismuth refinery $(\mathrm{Bi})$, niobium $(\mathrm{Nb})$, and phosphate $(\mathrm{P})$. The majority of these minerals were previously identified in the initial application of the earlywarning screening. This list of minerals will be further scrutinized via in-depth studies to determine which specific minerals should be classified as critical.

As noted in the initial assessment, no methodology can perfectly screen for critical minerals. Efforts are, however, underway to improve the early-warning screening in order to reduce the number of false-positive and false-negative determinations. This involves the use of historical events to retrospectively determine if such events would have been captured by the early-warning screening as a means 
a

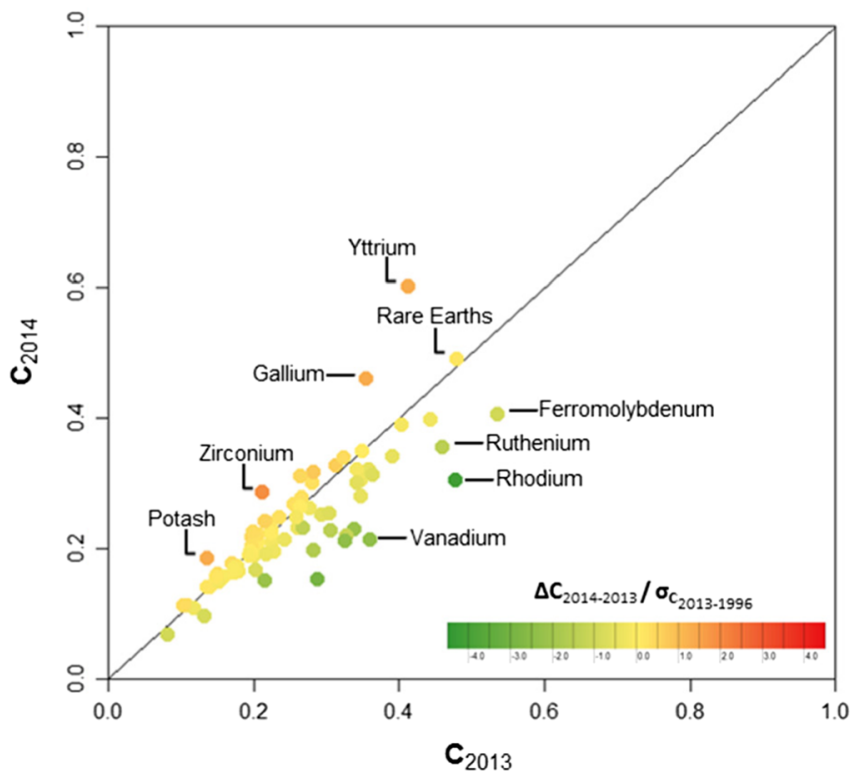

C

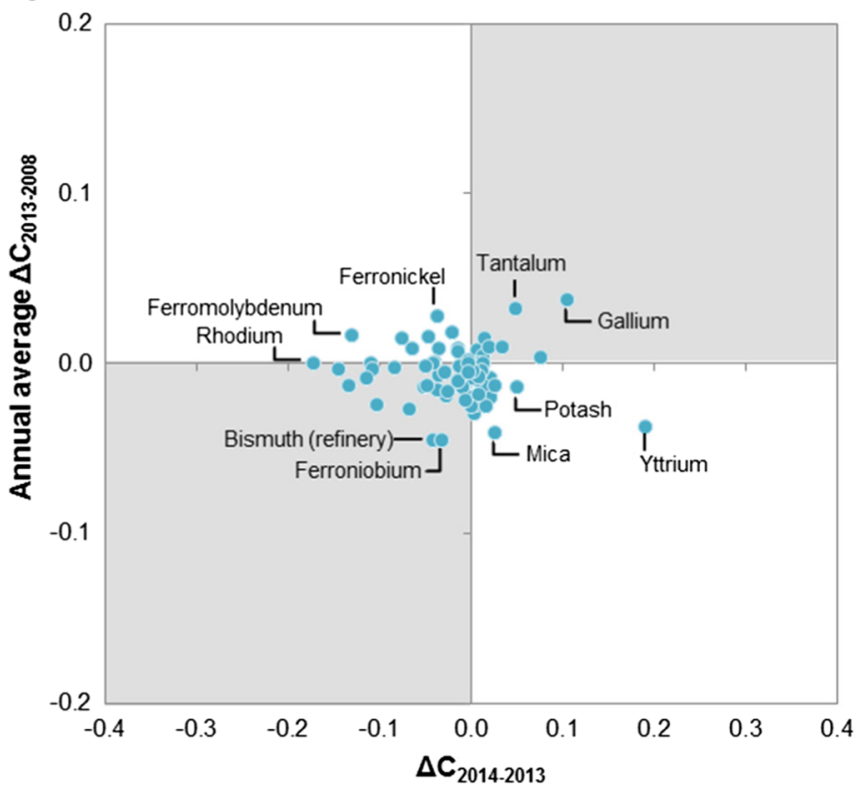

Fig. 12 a Scatterplot of $C$ values for years 2013 (horizontal axis) and 2014 (vertical axis). Distance from diagonal line indicates the magnitude of difference between the 2 years and point shading indicates the significance of that change relative to the standard deviation of $C$ values over the previous years. b Scatterplot of the change in the $C$ values between years 2013 and 2014 (horizontal axis) versus the significance of that change (vertical axis). Top and side figures display histograms of their respective axis. c Scatterplot of the change in the $C$

of model validation. Potential enhancements include adjustments to the time horizons utilized in both the $G$ and $M$ indicators and the utilization of additional, alternative, or modified indicators. Another potential enhancement that is being considered is the use of indicators that are specific to the situation in the USA. The early-warning b

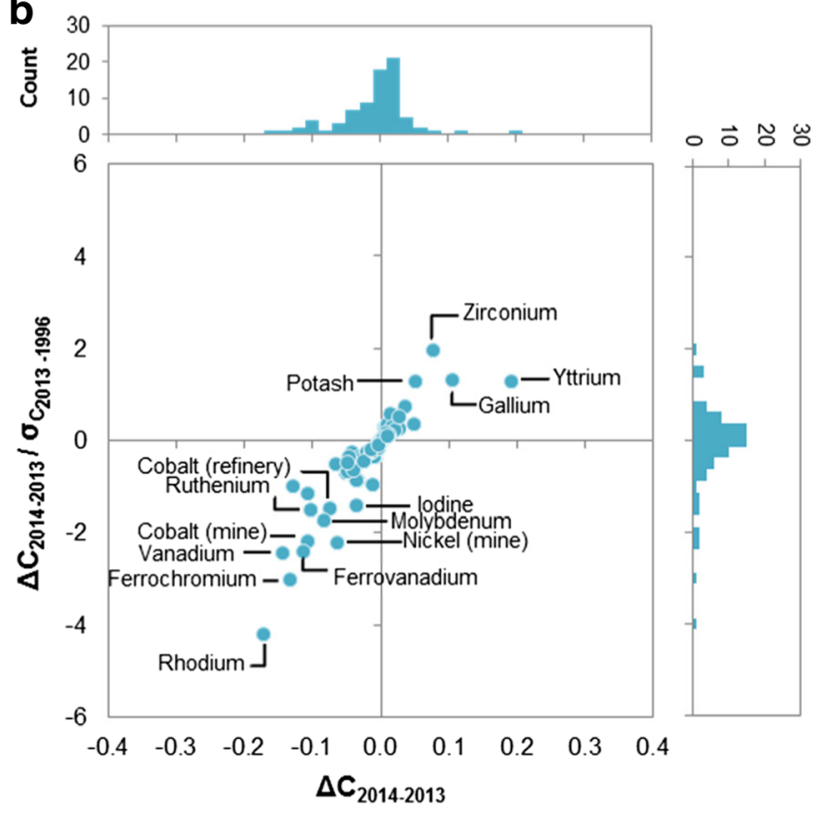

d

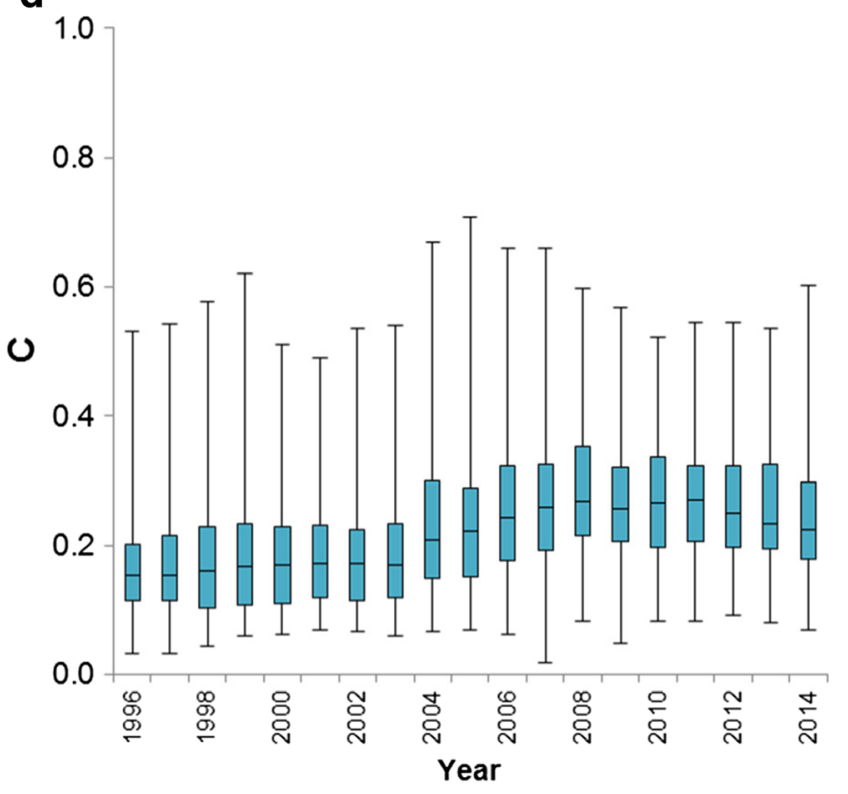

values between years 2013 and 2014 (horizontal axis) versus the annual average change in the $C$ values for years 2008 to 2013. Points in the gray quadrants indicate that the change in $C$ values between years 2013-2014 follows the previous 5-year trend, while those in the white quadrants have the opposite trend. d Distribution of the $C$ values across all minerals via a box-and-whisker plot displaying annual minimums, maximums, and interquartile ranges

screening methodology is currently country agnostic. The use of US-specific indicators including an indicator based on import reliance would focus the early-warning screening on potential vulnerabilities faced by the USA. These and other modifications will be explored as possible enhancements in future iterations on this assessment. 
Acknowledgements The authors appreciate the thoughtful recommendations provided by the signatory member agencies of the US National Science and Technology Council (NSTC) Subcommittee on Critical and Strategic Mineral Supply Chains. The authors would also like to thank all of the specialists and analysts at the National Minerals Information Center, US Geological Survey, for their input and feedback.

\section{Compliance with ethical standards}

Conflict of interest The authors declare that they have no conflict of interest.

Open Access This article is distributed under the terms of the Creative Commons Attribution 4.0 International License (http:// creativecommons.org/licenses/by/4.0/), which permits unrestricted use, distribution, and reproduction in any medium, provided you give appropriate credit to the original author(s) and the source, provide a link to the Creative Commons license, and indicate if changes were made.

\section{References}

Bae J-C (2010) Strategies and perspectives for securing rare metals in Korea. Critical elements for new energy technologies. MIT Energy Initiative, Boston

Bauer D, Diamond D, Li J et al (2010) Critical materials strategy. U.S. Department of Energy, Washington

Bauer D, Diamond D, Li J et al (2011) Critical materials strategy. U.S. Department of Energy, Washington

British Geological Survey (2016) Risk list 2011-2012:2015 http://www. bgs.ac.uk/mineralsuk/statistics/risklist.html

Buchert M, Schüler D, Bleher D (2009) Critical metals for future sustainable technologies and their recycling potential. United Nations Environment Programme, United Nations University, Paris

Butterman WC, Jorgenson JD (2005) Mineral commodity profiles: germanium. U.S. Geological Survey, Reston

Coulomb R, Dietz S, Godunova M, Nielsen TB (2015) Critical minerals today and in 2030: an analysis for OECD countries. OECD Publishing, Paris

Duclos S, Otto J, Konitzer G (2010) Design in an era of constrained resources. Mech Eng 132:36-40

European Commission (2010) Critical raw materials for the EU. Report of the Ad-Hoc Working Group on Defining Critical Raw Materials. European Commission, Brussels

European Commission (2014) Report on critical raw materials for the EU. European Commission, Brussels

Goonan TG (2012) Lithium use in batteries. Circular 1371. U.S. Geological Survey, Reston

Graedel TE, Barr R, Chandler C et al (2012) Methodology of metal criticality determination. Environ Sci Technol 46:1063-1070

Graedel TE, Harper EM, Nassar NT et al (2015) Criticality of metals and metalloids. Proc Natl Acad Sci 112:4257-4262. https://doi.org/10. 1073/pnas. 1500415112

Jorgenson JD, Michael GW (2005) Mineral commodity profile: indium. U.S. Geological Survey, Reston
Kaufmann D, Kraay A (2016) Worldwide governance indicators. The World Bank Group. http://info.worldbank.org/governance/wgi/ index.aspx\#home

Lederer GW (2016) Resource nationalism in Indonesia - effects of the 2014 mineral export ban. U.S. Geological Survey, Reston. https:// doi.org/10.3133/fs20163072

Lederer GW, Foley NK, Jaskula BW, Ayuso RA (2016) Beryllium-a critical mineral commodity - resources, production, and supply chain. U.S. Geological Survey, Reston. https://doi.org/10.3133/ fs 20163081

Loferski PJ (2016) Platinum-group metals. In: 2014 minerals yearbook. U.S. Geological Survey, Reston, VA, USA, p 57.1-57.12

J Matthey (2015) PGM market report 2015. http://www.platinum. matthey.com/services/market-research/pgm-market-reports

J Matthey (2016) Price charts, http://www.platinum.matthey.com/

Morley N, Eatherley D (2008) Material security-ensuring resource availability for the UK economy. Oakedene Hollins, C-Tech Innovation Ltd, Chester

Moss RL, Tzimas E, Willis P et al (2013) Critical metals in the path towards the decarbonisation of the EU energy sector. European Commission Joint Research Centre Institute for Energy and Transport, Luxembourg

Pfleger P, Lichtblau K, Kempermann H, et al (2011) Rohstoffsituation Bayern: Keine Zukunft ohne Rohstoff. Strategien und Handlungsoptionen [Status report on raw materials in Bavaria: no future without raw materials. Strategies and management options]. Vereinigung der Bayerischen e.V., Munich, Germany

Reichl C, Schatz M, Zsak G (2015) World mining data. International Organizing Committee for the World Mining Congresses, Vienna

Roelich K, Dawson DA, Purnell P et al (2014) Assessing the dynamic material criticality of infrastructure transitions: a case of low carbon electricity. Appl Energy 123:378-386. https://doi.org/10.1016/j. apenergy.2014.01.052

Rosenau-Tornow D, Buchholz P, Riemann A, Wagner M (2009) Assessing the long-term supply risks for mineral raw materials-a combined evaluation of past and future trends. Resour Policy 34: 161-175. https://doi.org/10.1016/j.resourpol.2009.07.001

Strategic Materials Protection Board (2008). Report of Meeting. Department of Defense. http://www.denix.osd.mil/cmrmp/ecmr/ beryllium/meetings/unassigned/jan-2009-defense-strategicmaterials-board-report-beryllium/

Thomason JS, Atwell RJ, Bajraktari Y et al (2010) From national defense stockpile (NDS) to strategic materials security program (SMSP): evidence and analytic support, Institute for Defense Analysis, Alexandria

U.S. Geological Survey (2016) Mineral commodity summaries 2016. U.S. Geological Survey, Reston

U.S. National Science and Technology Council (2016) Assessment of critical minerals: screening methodology and initial application. U.S. Office of Science and Technology Policy, Executive Office of the President, Washington

Ward JH (1963) Hierarchical grouping to optimize an objective function. J Am Stat Assoc 58:236-244

Yager TR (2016) The mineral industry of South Africa. In: 2013 minerals yearbook. U.S. Geological Survey, Reston

Zepf V, Simmons J, Reller A et al (2011) Materials critical to the energy industry: an introduction, 2nd edn. BP p.l.c, London 